\title{
Comparison of different methods to determine the degree of peat decomposition in peat bogs
}

\author{
H. Biester ${ }^{1}$, K.-H. Knorr ${ }^{2}$, J. Schellekens ${ }^{3}$, A. Basler ${ }^{4}$, and Y.-M. Hermanns ${ }^{1}$ \\ ${ }^{1}$ Institut für Geoökölogie, AG Umweltgeochemie, Technische Universität Braunschweig, Germany \\ ${ }^{2}$ Institute of Landscape Ecology, Hydrology Group, University of Muenster, Germany \\ ${ }^{3}$ Departamento de Edafoloxía e QuímicaAgrícola, University of Santiago de Compostela, Fac. de Bioloxía, Campus \\ Universitario Sur 15782 Santiago de Compostela, Spain \\ ${ }^{4}$ Centre for Stable Isotopes and Analysis, Büsgen Institute, University of Göttingen, Germany \\ Correspondence to: H. Biester (h.biester@tu-bs.de)
}

Received: 8 September 2013 - Published in Biogeosciences Discuss.: 5 November 2013

Revised: 29 March 2014 - Accepted: 7 April 2014 - Published: 21 May 2014

\begin{abstract}
Peat humification or decomposition is a frequently used proxy to extract past time changes in hydrology and climate from peat bogs. During the past century several methods to determine changes in peat decomposition have been introduced. Most of these methods are operationally defined only and the chemical changes underlying the decomposition process are often poorly understood and lack validation. Owing to the chemically undefined nature of many humification analyses the comparison of results obtained by different methods is difficult. In this study we compared changes in peat decomposition proxies in cores of two peat bogs (Königsmoor, KK; Kleines Rotes Bruch, KRB) from the Harz Mountains (Germany) using $\mathrm{C} / \mathrm{N}$ ratios, Fourier transform infrared spectra absorption (FTIR) intensities, Rock Eval ${ }^{\circledR}$ oxygen and hydrogen indices, $\delta^{13} \mathrm{C}$ and $\delta^{15} \mathrm{~N}$ isotopic signatures and UV-absorption (UV-ABS) of $\mathrm{NaOH}$ peat extracts. In order to explain parallels and discrepancies between these methods, one of the cores was additionally analysed by pyrolysis gas chromatography mass spectrometry (pyrolysis-GC-MS). Pyrolysis-GC-MS data provide detailed information on a molecular level, which allows differentiation of both changes attributed to decomposition processes and changes in vegetation. Principal component analysis was used to identify and separate the effects of changes in vegetation pattern and decomposition processes because both may occur simultaneously upon changes in bog hydrology. Records of decomposition proxies show similar historical development at both sites, indicating external forcing such as climate as controlling the process. All decomposition proxies except UV-ABS and $\delta^{15} \mathrm{~N}$ isotopes show similar patterns
\end{abstract}

in their records and reflect to different extents signals of decomposition. The molecular composition of the KK core reveals that these changes are mainly attributed to decomposition processes and to a lesser extent to changes in vegetation. Changes in the molecular composition indicate that peat decomposition in the KK bog is mainly characterized by preferential decomposition of phenols and polysaccharides and relative enrichment of aliphatics during drier periods. Enrichment of lignin and other aromatics during decomposition was also observed but showed less variation than polysaccharides or aliphatics, and presumably reflects changes in vegetation associated with changes in hydrology of the bogs. Significant correlations with polysaccharide and aliphatic pyrolysis products were found for $\mathrm{C} / \mathrm{N}$ ratios, FTIR-band intensities and for hydrogen index values, supporting that these decomposition indices provide reasonable information. Correlations of polysaccharide and aliphatic pyrolysis products with oxygen index values and $\delta^{13} \mathrm{C}$ was weaker, assumingly indicating carboxylation of the peat during drier periods and enrichment of isotopically lighter peat components during decomposition, respectively. FTIR, $\mathrm{C} / \mathrm{N}$ ratio, pyrolysisGC-MS analyses and Rock Eval hydrogen indices appear to reflect mass loss and related changes in the molecular peat composition during mineralization best. Pyrolysis-GC-MS allows disentangling the decomposition processes and vegetation changes. UV-ABS measurements of alkaline peat extracts show only weak correlation with other decomposition proxies and pyrolysis results as they mainly reflect the formation of humic acids through humification and to a lesser extent mass loss during mineralization. 


\section{Introduction}

Many studies have used ombrotrophic bogs as archives to reconstruct climate or environmental conditions of the past (Barber, 2006; Barber and Langdon, 2007). Changes of the physical-chemical conditions through time or changes in vegetation offer different proxies for past environmental conditions (Chambers et al., 2012; Charman et al., 2009, and references therein). Some of these proxies, such as pollen, dust, volcanic ash or trace elements and pollutants from anthropogenic sources, are related solely to atmospheric deposition and may therefore be considered as "external" proxies, reflecting changes on a local or regional scale. Such proxies are thought to be mostly unaffected by internal processes of peat formation, although an influence of decomposition on trace element records has been reported (Biester et al., 2012, 2004, 2003; Martínez Cortizas et al., 2007). In addition to these external proxies, a number of internal proxies exist which describe changes of the bog vegetation (Booth, 2010; Charman et al., 2006; McMullen et al., 2004) or of the water table position over time, such as non-pollen palynomorphs (Mighall et al., 2006) or testate amoebae (Hendon et al., 2001; Woodland et al., 1998). The strongest factor controlling peat accumulation is the ratio between peat formation and decay of organic matter (OM). This is mainly dependent on the climatic or hydrological conditions, resulting redox conditions and the availability of nutrients. Since in ombrotrophic bogs, nutrient supply is limited to atmospheric deposition and therefore generally low, the most important factor for peat decomposition is the oxygen availability controlled by position of the water table. Because of the critical role of the water table (Ise et al., 2008), a bog's profile is generally separated into two sections: (i) the permanently water logged catotelm, characterized by anoxic conditions and slow peat decay, and (ii) the temporally aerated acrotelm, where decomposition is generally fast and most of the initial plant mass is mineralized (Kuhry and Vitt, 1996; Malmer and Holm, 1984; Malmer and Wallén, 2004). It is therefore generally recognized that peat decomposition is low during times of high water table levels or wet climatic conditions, but high during times of low water table levels or dry climatic conditions (Clymo, 1984). Accordingly, the degree of peat decomposition in the historic profile reflects the hydrological conditions during the time of peat formation, or more exactly at the time of peat burial in the catotelm. It has to be noted, though, that repeated dryfalling and re-wetting cycles might also affect deeper and older peat layers and modify and superimpose the historic record of peat decomposition. This latter process, named secondary decomposition, can therefore result in a decoupling of the age versus depth relationship between peat formation and peat decomposition (Biester et al., 2007; Steinmann et al., 2006).

A problem in the discussion and comparison of changes in peat decomposition addressed in different studies is that the chemical changes during decomposition are often not clearly defined. In many studies the term humification is used, which solely addresses the formation of humic acids containing UV absorbing aromatic components (Blackford and Chambers, 1993; Klavins et al., 2008). The term decomposition as used here encompasses mass loss during mineralization causing selective preservation of more resistant compounds, and transformations of the remaining OM.

Since early investigations of peat bogs as climate archives in the 1920s, several chemical and physical methods have been developed to determine the degree of peat decomposition. The von Post scale (von Post, 1922) divides the degree of peat decomposition into 10 grades, based on the colour of the manually squeezed peat pore water and the remaining solid material. Later, a number of mostly alkaline extraction procedures have been developed which all aim to extract and quantify humic or fulvic acids from the peat as a measure of peat decomposition. Aaby and Tauber (1975) used Bahnson's (1968) alkaline extraction $(\mathrm{NaOH})$ procedure combined with UV absorption (UV-ABS) measurements to determine differences in the degree of peat humification based on the leachate's colour intensity, and related this to bog surface wetness at the time of peat formation. Blackford and Chambers (1993) compared this colorimetric "determination of peat humification" for reconstructing past bog surface wetness with various other simple methods (such as fibre content; von Post visual humification scale), and considered fibre content and the colorimetric technique to be superior. However, because "percentage of peat humification" is a dubious concept, they recommended that results from colorimetry should instead be reported using percentage light transmission values. A revised protocol for this colorimetric method was published recently by Chambers et al. (2011). However, other factors can also influence the abundance of humic acids, such as botanical changes (Yeloff and Mauquoy, 2006; Chambers et al., 1997).

Peat decomposition has also been intensively investigated by coal petrologists (Outridge and Sanei, 2010) often using Rock $\mathrm{Eval}^{\odot}{ }^{\circledR}$ pyrolysis to determine $\mathrm{H} / \mathrm{C}$ and $\mathrm{O} / \mathrm{C}$ ratios (Carrie et al., 2012; Lafargue et al., 1998; Langford and Blanc-Valleron, 1990). This approach relies on the assumption that during decomposition of OM, labile compounds such as polysaccharides are preferentially decomposed while refractory aromatic or aliphatic compounds become residually enriched, causing a decrease of $\mathrm{O} / \mathrm{C}$ and $\mathrm{H} / \mathrm{C}$ ratios (Klavins et al., 2008).

Another common proxy of peat decomposition is the use of $\mathrm{C} / \mathrm{N}$ ratios (Kuhry and Vitt, 1996; Malmer and Holm, 1984). This approach is based on the observed residual enrichment of $\mathrm{N}$ relative to $\mathrm{C}$ during mineralization of $\mathrm{OM}$, i.e. lower $\mathrm{C} / \mathrm{N}$ ratios of more decomposed peat material. Thus, changes in $\mathrm{C} / \mathrm{N}$ ratios are postulated to indicate mainly changes in bog surface wetness and concomitant changes in peat decomposition. However, $\mathrm{C} / \mathrm{N}$ ratios differ widely between peatland plants (Hornibrook et al., 2000), and thus shifts in vegetation upon changes in surface wetness affect 
$\mathrm{C} / \mathrm{N}$ ratios in peat and may obscure the signal of decomposition.

Owing to the turnover of $\mathrm{OM}$ and associated $\mathrm{C}$ losses in mires, a relation between peat decomposition and stable isotope inventories of hydrogen $(\mathrm{H}), \mathrm{C}, \mathrm{N}$, sulfur $(\mathrm{S})$ and oxygen (O) would also be expected. However, the fate of H, C, N, S, $\mathrm{O}$ stable isotopes during peat decomposition and their use as indicators is discussed controversially. Some studies used C, $\mathrm{N}, \mathrm{S}, \mathrm{O}$ stable isotopes to reconstruct past temperature or humidity (Skrzypek et al., 2009; Jones et al., 2010) and found support that the isotopic signature of the peat reflects that of the former living plant and is not affected by decomposition, at least if specific parts of plants are investigated (Skrzypek et al., 2007). Other studies found a rapid decrease in $\delta^{13} \mathrm{C}$ in the upper peat layers attributed to the preferential decay of cellulose over lignins, the latter being isotopically lighter (Benner et al., 1987). Methane formation causes a strong increase in ${ }^{13} \mathrm{C}$ content of the residual peat (Charman et al., 1999; Quay et al., 1999; Jones et al., 2010). Therefore, the use of stable isotopes to elucidate decomposition processes is so far not fully constrained.

Klavins et al. (2008) compared a number of indicators for peat humification based on changes in some quality indices. They distinguished between a humification index, pyrophosphate index, humus quality, peat humification index, humification degree and several element ratios such as the $\mathrm{H} / \mathrm{C}$, $\mathrm{O} / \mathrm{C}$ and the $\mathrm{N} / \mathrm{C}$ ratio. Most of these indices are, however, operationally defined and it remains unresolved by which biogeochemical processes these indices are controlled.

A spectroscopic approach to overcome the limitations of operationally defined parameters of peat decomposition is the use of Fourier transform infrared spectra absorption (FTIR) spectroscopy. This technique is used in peat and soil OM studies to distinguish the principal chemical classes such as carbohydrates, lignin, aliphatics, lipids and proteins through the vibrational characteristics of their chemical bonds (Artz et al., 2008; Cocozza et al., 2003; Senesi et al., 1991). Several studies used the relative intensities of FTIR absorption bands to evaluate the degree of peat decomposition (e.g. Artz et al., 2008; Broder et al., 2012; Kalbitz et al., 1999). An overview of FTIR absorption bands of peat humic acids and their assignment to defined chemical groups in peat can be found in Niemeyer et al. (1992).

Several approaches have been made to compare decomposition proxies in peat (Borgmark and Schoning, 2006; Klavins et al., 2008). However, most studies compare a small number of humification proxies or indices, only, and neglect changes in the botanical setting. Moreover, comparisons of these methods with methods that provide detailed structural information in peat have only been applied in a few cases (Disnar et al., 2008; Halma et al., 1984; Bourdon et al., 2000).

Pyrolysis-GC-MS is a powerful method to characterize complex mixtures of OM such as peat (Buurman et al., 2006; Kracht and Gleixner, 2000; van der Heijden and Boon,
1994; van der Heijden et al., 1990; van Smeerdijk and Boon, 1987) and has been successfully applied to determine past environmental conditions from peat records (Boon et al., 1986; Kuder and Kruge, 1998; McClymont et al., 2011; Schellekens et al., 2012; Schellekens et al., 2011). Pyrolysis-GC-MS provides on the one hand molecular vegetation markers, which allow deciphering past changes in the bog's surface vegetation and, on the other hand, changes in the relative abundance of easily degradable and more resistant compounds that can be related to historical changes in peat decomposition linked to water table controlled redox conditions. Despite the fact that pyrolysis-GC-MS data are semi-quantitative, good agreement of peat pyrolysis data had been observed with $\mathrm{C} / \mathrm{N}$ ratios (Schellekens and Buurman, 2011), spectroscopic methods such as FTIR (González et al., 2003) and ${ }^{13}$ C NMR (Buurman et al., 2006; Kaal et al., 2007; Pontevedra-Pombal et al., 2001).

The main aim of this study is to evaluate the extent to which common peat decomposition proxies compare with peat structural components and to discuss their value as indicators of historical changes in peat decomposition. We analysed bulk samples of peat cores and plants from two ombrotrophic mires of the Harz Mountains for $\mathrm{C} / \mathrm{N}$ ratios, $\mathrm{HI}$ and OI indices obtained by Rock Eval analyses, FTIRspectra band intensities, $\delta^{13} \mathrm{C}$ and $\delta{ }^{15} \mathrm{~N}$ isotope fractionation and UV-absorption of $\mathrm{NaOH}$ humic acid extracts. Most of these peat decomposition proxies are potentially influenced by both vegetation changes and decomposition processes, which are both mainly controlled by the bog's surface wetness. To disentangle these processes we analysed one of the cores with pyrolysis-GC-MS. The detailed structural information obtained with analytical pyrolysis was used as the basis for the interpretation of the peat decomposition indicators. The relationship between decomposition proxies and molecular composition of the peat was evaluated by means of principal component analysis (PCA) to decipher underlying biogeochemical processes (factors) related either to decomposition and/or to changes in vegetation pattern.

\section{Materials and methods}

\subsection{Sampling and sampling sites}

Peat cores were sampled from two bogs located in the central Harz Mountains (Germany) (Supplement Fig. S1). Both mires, Königsmoor (KK, $83 \mathrm{~cm}$; 51 $45^{\prime} 58.89^{\prime \prime} \mathrm{N}$, $\left.10^{\circ} 34^{\prime} 50.31^{\prime \prime} \mathrm{E}\right)$ and Kleines Rotes Bruch (KRB, $97 \mathrm{~cm}$; $\left.51^{\circ} 45^{\prime} 1.83^{\prime \prime} \mathrm{N}, \quad 10^{\circ} 35^{\prime} 4.59^{\prime \prime} \mathrm{E}\right)$ are situated at $730-$ $850 \mathrm{ma}$ a.s.l., respectively. The ombrothrophic parts of the bogs cover an area of 0.66 ha $(\mathrm{KK})$ and 2.65 ha (KRB), respectively. Peat growth started about $11000-$ 11500 years BP. Present-day vegetation is dominated by Sphagnetum magellanici (Baumann, 2009). Peat cores were taken in lawns from each site by means of a $100 \mathrm{~cm}$ long 
Pürckhauer soil corer and were cut into $2 \mathrm{~cm}$ sections, deep frozen, freeze dried and milled in an agate ball mill.

Plants were sampled at the KK and the KRB bog, washed, freeze dried and milled in an agate ball mill before analysis. For all analyses bulk plant samples were used.

\subsection{Determination of peat decomposition indicators}

\subsubsection{Pyrolysis-GC-MS}

Platinum filament coil probe pyrolysis (temperature $650^{\circ} \mathrm{C}$ ) was performed with a Pyroprobe 5000 pyrolyser (CDS, Oxford, USA) coupled to a 6890N GC and 5975B MSD GC/MS system from Agilent Technologies (Palo Alto, USA). Samples were embedded in quartz tubes using glass wool. The pyrolysis interface and GC inlet (split ratio $1: 20$ ) were set at $325^{\circ} \mathrm{C}$. The $\mathrm{GC}$ instrument was equipped with a (nonpolar) HP-5MS $5 \%$ phenyl, $95 \%$ dimethyl-polysiloxane column (length $30 \mathrm{~m}$; internal diameter $0.25 \mathrm{~mm}$; film thickness $0.25 \mu \mathrm{m}$ ). Helium was used as the carrier gas (constant gas flow of $\left.1 \mathrm{~mL} \mathrm{~min}^{-1}\right)$. The oven temperature program was 50 to $325^{\circ} \mathrm{C}$ (held $10 \mathrm{~min}$ ) at $15^{\circ} \mathrm{C} \mathrm{min}^{-1}$. The GC/MS transfer line was held at $270^{\circ} \mathrm{C}$, the ion source (electron impact mode, $70 \mathrm{eV}$ ) at $230^{\circ} \mathrm{C}$, the quadrupole ion filter and the detector at $150{ }^{\circ} \mathrm{C}$, scanning a range between $\mathrm{m} / z$. 50 and 500 . Compounds were identified using the NIST'05 library.

For the eight analysed plant species all visible peaks were identified, of which six pyrolysis products appeared to be valuable as markers for one species or for a group of species. A marker is here defined as a pyrolysis product which is (i) exclusively found in one of the investigated species and (ii) well preserved in the peat. The term "marker" is used here for pyrolysis products that were specific within the analysed data set and in previous studies (Schellekens et al., 2011; Schellekens et al., 2009; Schellekens et al., 2013). Such markers may only be valid within the current study, as their presence in other species cannot be excluded, and thus the use of the term "marker" is provisional.

Based on frequency, abundance and potential as vegetation marker, a selection of 84 pyrolysis products was quantified for all 42 peat samples of the KK core. Quantification was based on the peak area of characteristic ions $(m / z)$ from each pyrolysis product (Supplement Table S1). For each sample the sum of the quantified peak areas was set at $100 \%$ and amounts were calculated relative to this. According to probable origin and similarity, the pyrolysis products were grouped as follows: polysaccharides, aliphatics ( $n$-alkanes, $n$-alkenes, methyl ketones, fatty acids, other aliphatic compounds), lignins, phenols, aromatics, polyaromatics and nitrogen compounds.

\subsection{2 $\mathrm{C} / \mathrm{N}$ ratios and $\mathrm{C}$ and $\mathrm{N}$ stable isotope analyses}

Concentrations of $\mathrm{C}$ and $\mathrm{N}$ were determined in the carbonate free, acid peat by gas chromatography and thermal con- ductivity detection after thermal combustion in an elemental analyser (Euro EA3000, Eurovector). Reproducibility of duplicates was always better than $\sim 8 \%$ RSD.

Ratios of ${ }^{13} \mathrm{C} /{ }^{12} \mathrm{C}$ and ${ }^{15} \mathrm{~N} /{ }^{14} \mathrm{~N}$ and total $\mathrm{C}$ and $\mathrm{N}$ were quantified in dried bulk plant material and peat on mass basis using an elemental analyser (CE instruments NA 1108, Milan, Italy), connected via ConFlo III interface to a delta S IR-MS (Thermo Finnigan MAT, Bremen, Germany). Isotope signatures are given in the $\delta$-notation $\delta \%_{0}=\left(\left(R_{\text {sample }} / R_{\text {standard }}\right)-1\right) \times 10^{3}$, relative to the V-PDB standard or $\mathrm{N}_{2}$ in ambient air.

\subsubsection{FTIR spectra}

FTIR spectra of the ground peat samples were obtained using a Vector 22 FTIR spectrometer (Bruker Optik, Ettlingen, Germany; absorption mode, subsequent baseline subtraction) on $\mathrm{KBr}$ pellets ( $200 \mathrm{mg}$ dried $\mathrm{KBr}$ and $2 \mathrm{mg}$ sample). Measurements were recorded from 4500 to $300 \mathrm{~cm}^{-1}$ using a resolution of $2 \mathrm{~cm}^{-1}$. A number of 32 scans per sample were averaged. Absorption peaks indicative of structural units in $\mathrm{OM}$ were identified according to Senesi et al. (1989) and Niemeyer et al. (1992) and used as indicators of peat $\mathrm{OM}$ quality. Absorption at $1420 \mathrm{~cm}^{-1}$ is ascribed to $\mathrm{OH}$ deformations and $\mathrm{CO}$ stretch of phenols or $\mathrm{CH}$ deformation of $\mathrm{CH}_{2}$ or $\mathrm{CH}_{3}$ groups (phenolic and aliphatic structures), at $\sim 1510 \mathrm{~cm}^{-1}$ to aromatic $\mathrm{C}=\mathrm{C}$ or to $\mathrm{CO}$ of amide groups. The $\sim 1630 \mathrm{~cm}^{-1}$ region is indicative of aromatic $\mathrm{C}=\mathrm{C}$ and asymmetric $\mathrm{COO}^{-}$group vibrations (lignin and other aromatics and aromatic or aliphatic carboxylates) and $\sim 1720 \mathrm{~cm}^{-1}$ of CO stretch of carbonyl and carboxyl groups (carboxylic acids and aromatic esters). The $2920 \mathrm{~cm}^{-1}$ and $2850 \mathrm{~cm}^{-1}$ bands reflect C-H stretching vibrations, and $460 \mathrm{~cm}^{-1}$ can be assigned to substituted aromatics and unsaturated aliphatic chains, which agrees with aromatic and aliphatic pyrolysis products. However, this band may be influenced by minerals such as clays and is thus not further considered here. Multiple signals at $1707 \mathrm{~cm}^{-1}(\mathrm{C}=\mathrm{O}), 1620 \mathrm{~cm}^{-1}(\mathrm{C}=\mathrm{O}, \mathrm{C}=\mathrm{C}), 1510 \mathrm{~cm}^{-1}$ $(\mathrm{C}=\mathrm{C}), 1420 \mathrm{~cm}^{-1}\left(\mathrm{CH}_{2}\right.$, heterocyclics $), 1370 \mathrm{~cm}^{-1}(\mathrm{C}-$ $\mathrm{H}$, phenolics) and $1265 \mathrm{~cm}^{-1}(\mathrm{C}-\mathrm{O}, \mathrm{C}-\mathrm{O}-\mathrm{C})$ agree with lignin or alike compounds; strong bands at $3370 \mathrm{~cm}^{-1}$ (O$\mathrm{H}), 1151 \mathrm{~cm}^{-1}$ (C-O, cellulose, carbohydrates), $1032 \mathrm{~cm}^{-1}$ (C-O, cellulose, carbohydrates) and $891 \mathrm{~cm}^{-1}$ (O-H, carbohydrates) bands agree with polysaccharides.

To determine relative abundances of functional groups as a humification index, the ratio between peak intensity at $1630 \mathrm{~cm}^{-1}$ with respect to polysaccharides $\left(1053 \mathrm{~cm}^{-1}\right)$ was calculated (Holmgren and Norden, 1988; Niemeyer et al., 1992). 


\subsubsection{Oxygen and hydrogen indices using the Rock Eval $^{\circledR}$ method}

Rock Eval analyses were performed at the Alfred Wegener Institut für Polar- und Meeresforschung in Bremerhaven, Germany, using a Rock-Eval II (plus S3 unit). The method determines several operational defined groups of organic compounds based on pyrolysis at different temperatures and different $\mathrm{H} / \mathrm{C}$ and $\mathrm{O} / \mathrm{C}$ ratios. The obtained results allow distinguishing between labile and increasingly refractory OM fractions (Tissot and Welte, 1978). Pyrolysis is conducted on bulk peat samples $(20 \mathrm{mg})$ to determine the amount of (i) hydrocarbons present in the sample (S1 peak in milligrams of hydrocarbons per gram of peat, data not shown), (ii) the amount of hydrocarbons generated by pyrolytic degradation of the peat during heating up to $550{ }^{\circ} \mathrm{C}$ (S2 peak in mg hydrocarbon per gram sediment) defined as the Hydrogen Index (HI) when normalized to the total organic $\mathrm{C}$ content, and (iii) the amount of carbon dioxide generated during heating up to $390^{\circ} \mathrm{C}$ (S3 peak in milligrams carbon dioxide per gram sediment), which gives the Oxygen Index (OI), when normalized to the total OM content (Lafargue et al., 1998).

\subsubsection{Humic acids extraction and UV-absorption}

The colorimetric method for characterizing the degree of decomposition was adopted by Blackford and Chambers (1993). For this study $0.1 \mathrm{~g}$ pulverized and freeze-dried peat samples were dissolved in $50 \mathrm{~mL} \mathrm{NaOH}(8 \%)$ and placed on a hot plate for $1 \mathrm{~h}$ to simmer. After cooling the extract was filled up to $100 \mathrm{~mL}$ with deionized water and filtered through a Whatman No. 1 filter paper. Then $25 \mathrm{~mL}$ of the extract were diluted to $50 \mathrm{~mL}$ prior to the colorimetric measurement. The absorbance of light (in \%) was measured with a Perkin-Elmer UV-Vis spectrometer at a wavelength of $540 \mathrm{~nm}$ (UV-ABS).

\subsubsection{Statistical analyses}

Statistical analyses were performed using PASW Statistics 18.0 (IBM Corporation). All data were tested for correlation with a level of significance $p<0.05$ (Pearson, two-tailed). PCA was applied to extract the chemical signatures of the OM composition to derive the underlying factors accounting for them. The analysis was performed in the $Z$-score transformation $\left(Z\right.$ score $=\left(X_{i}-X_{\text {avg }}\right) / X_{\text {std }}$; where $X_{i}$ is a given value of a variable in a sample, $X_{\text {avg }}$ is the average of that variable and $X_{\text {std }}$ is its standard deviation). $Z$ scores allow keeping the relative variation of the original data while reducing all variables to a similar range of variation avoiding scaling effects (Eriksson et al., 1999). For the pyrolysis products, factor analysis was performed using Statistica 6 (StatSoft, Tulsa). PCA was applied for the complete data set of the KK core including pyrolysis-GC-MS and decomposition data. In addition data on decomposition proxies of both cores (KK and KRB) was evaluated by PCA, separately.

\section{Results}

\subsection{Carbon nitrogen ratios and isotopic composition of peat-forming plants}

Results of $\mathrm{C}$ and $\mathrm{N}$ analyses of plants show highest $\mathrm{C} / \mathrm{N}$ ratios for Sphagnum as compared to Calluna vulgaris (Ericaceae) and Eriophorum vaginatum (Cyperaceae), which are considered as the most important peat-forming plants in the Harz bogs (Table 1). $\delta^{13} \mathrm{C}$ values range between $-27.09 \%$ o and $-29.21 \%$ and are therefore similar in the three investigated species, but significantly lighter in $C$. vulgaris. In contrast to $\delta^{13} \mathrm{C}, \delta^{15} \mathrm{~N}$ vary in a broad range between $-0.87 \%$ o and $-8.13 \%$, with $C$. vulgaris being lightest.

\subsection{Molecular composition of KK peat determined by pyrolysis-GC-MS}

Molecular components were only determined in the KK core, assuming a similar relationship between the molecular components and the traditional decomposition proxies in both bogs (KK and KRB).

\subsubsection{Vegetation markers}

Based on analysis of plant species (Eriophorum vaginatum, Sphagnum and Calluna vulgaris) and on previous plant analyses several markers were identified. 4-Isopropenylphenol is specific for Sphagnum moss (Ph5) (van der Heijden et al., 1997). Additionally two biphenyl compounds were solely detected in Sphagnum (Ph7, Ph9; Supplement Table S1). 3Methoxy-5-methylphenol $(\mathrm{Ph} 6, \mathrm{~m} / z \mathrm{107}, 109,138)$ is characteristic for several lichen species (Schellekens et al., 2011; Schellekens et al., 2009). Ferulic acid methyl ester ( $\mathrm{Ph} 8, \mathrm{~m} / \mathrm{z}$ $145,177,208)$ was only detected in E. vaginatum and has been proposed as a marker of graminoids (Schellekens et al., 2011; Schellekens et al., 2013). A sesquiterpene (St1) was solely detected in the pyrolysate of Pinus. Three unidentified compounds with $m / z 86$ and 114 were present in the peat OM, but were not detected in any of the analysed plant species. All three probably originate from the same macromolecule as the difference between their molecular masses $\left(\mathrm{M}^{+} 182,210\right.$ and 238) point towards two $\mathrm{CH}_{2}$ groups. Only the compound with molecular mass 210 (unkn3) was quantified, as it showed the highest abundance.

\subsubsection{Peat record}

The mean abundance of groups of pyrolysis products for the KK peat record is given in Table 2. A detailed listing of all quantified pyrolysis products and their mean abundance in the peat OM is given in Supplement Table S1. As shown in 
Table 1. Average carbon and nitrogen isotope ratios and $\mathrm{C} / \mathrm{N}$ ratios in plants from two Harz Mountain bogs (KK, KRB). Standard deviation of repeated measurements of isotopic composition were $<0.5 \%$ and $<0.25 \%$ for $\delta^{15} \mathrm{~N}$ and $\delta^{13} \mathrm{C}$, respectively.

\begin{tabular}{lccc}
\hline $\begin{array}{l}\text { Plant } \\
\text { species }\end{array}$ & $\begin{array}{r}\mathrm{C} / \mathrm{N} \\
\text { ratios }\end{array}$ & $\begin{array}{c}\delta^{13} \mathrm{C} \\
(\% \circ)\end{array}$ & $\begin{array}{c}\delta^{15} \mathrm{~N} \\
(\% o)\end{array}$ \\
\hline $\begin{array}{l}\text { Sphagnum magellanicum }(n=3) \\
\text { Calluna vulgaris }(n=3)\end{array}$ & 37.55 & -27.67 & -3.58 \\
Eriophorum $(n=3)$ & 28.58 & -27.21 & -8.13 \\
\hline
\end{tabular}

Table 2, polysaccharides are by far the most abundant organic compound in the peat followed by much smaller amounts of aliphatics, lignins, phenols and aromatics. We selected five molecular proxies including plant-specific markers for Sphagnum and pine, and groups of pyrolysis products. Based on their distribution these proxies can roughly be divided into two groups, where polysaccharides and the marker of Sphagnum (4-isopropenylphenol) on one hand and aliphatics and the marker of pine (sesquiterpene) on the other, showed similar changes (Fig. 1), whereas the distribution of lignin pyrolysis products shows smaller variations and less similarity to the distribution of aliphatics. All five groups of components except lignin show the highest variability in the upper $50 \mathrm{~cm}$ of the core. Polysaccharides and 4-isopropenylphenol show a trend of declining values towards the surface with pronounced minima between about 8 and 15 and 25 and $38 \mathrm{~cm}$ depth and a clear maximum between 38 and $50 \mathrm{~cm}$ depth (Fig. 1). Aliphatics and sesquiterpene show the opposite trend, also increasing below $\sim 70 \mathrm{~cm}$.

\subsection{Records of decomposition proxies}

\subsubsection{Königsmoor (KK)}

$\mathrm{C} / \mathrm{N}$ ratios in the $\mathrm{KK}$ core show lowest values in the surface layer and increase down to a depth of $50 \mathrm{~cm}$ where they reach their maximum (Fig. 2). A pronounced peak of high $\mathrm{C} / \mathrm{N}$ ratios indicating relatively low decomposition is observed between $\sim 43$ and $50 \mathrm{~cm}$. Below $50 \mathrm{~cm}$ they show some variation but no more trends towards the end of the core. A similar trend of increasing values with depth is also observed for $\delta^{13} \mathrm{C}$ values as well as for UV-ABS and $\delta^{15} \mathrm{~N}$ (Fig. 2 and Supplement Table S3). Neither HI and OI values show a trend despite intense changes throughout the core. The records of both values seem to show an inverse relationship, with highest OI and lowest HI values in the surface layer, but are not significantly correlated (Supplement Table S3). Most intense variability is observed in the section between $\sim 38$ and $50 \mathrm{~cm}$ depth corresponding to similar intense changes of the other proxies in the same section (Fig. 2). UV-ABS is lowest in the surface layer and increases down to $40 \mathrm{~cm}$ by a factor of 2.5 after a pronounced low between 38 and $50 \mathrm{~cm}$ values again slightly increase towards the bottom of the core with-

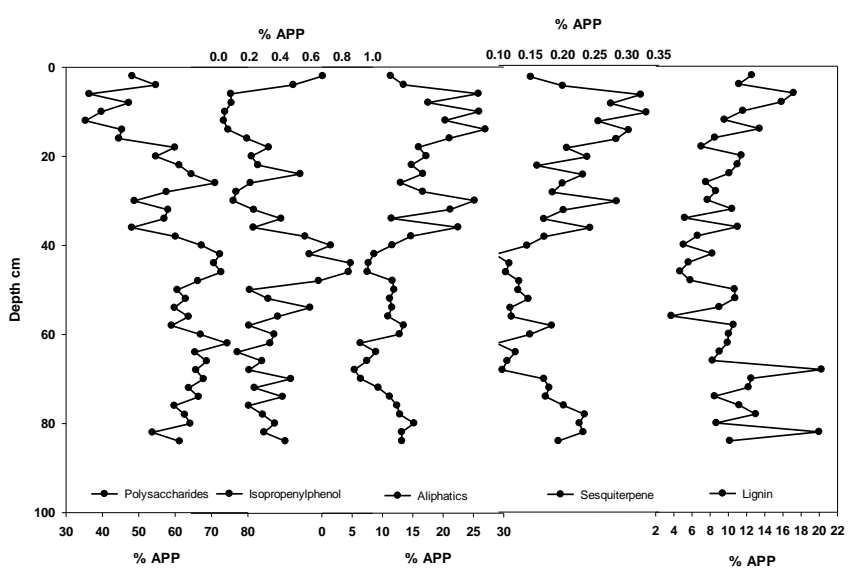

Figure 1. Distribution of selected (groups of) pyrolysis products in the KK peat record indicative for polysaccharides, aliphatics and lignin, the markers of Sphagnum (4-Isopropenylphenol) and Pinus (sesquiterpene). Values show percentages of bulk samples relative to the sum of all quantified pyrolysis products (APPs).

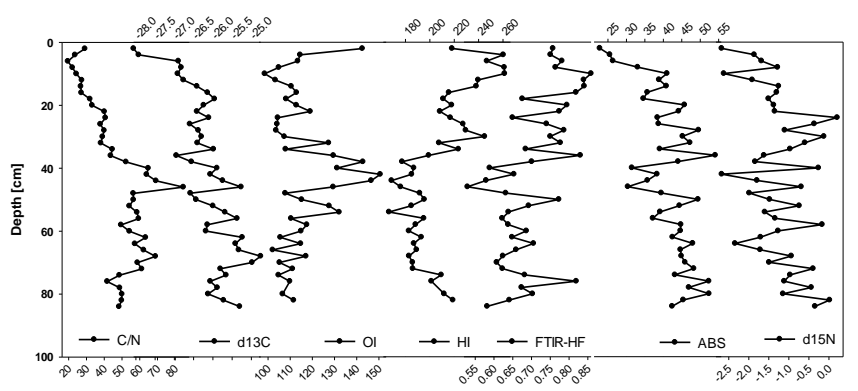

Figure 2. Records of decomposition proxies: $\mathrm{C} / \mathrm{N}$ ratios, $\delta^{13} \mathrm{C}(\%)$, oxygen and hydrogen indices (OI, HI $\left(\mathrm{mgCO} \mathrm{g}^{-1}\right.$ TOC)) determined by Rock Eval ${ }^{\circledR}$ analyses, FTIR decomposition index $1630 / 1053 \mathrm{~cm}^{-1}$, UV-ABS of $\mathrm{NaOH}$ peat extracts and $\delta^{15} \mathrm{~N}(\% \circ)$ in bulk peat of the KK core.

out larger changes. There are, however, almost no common features with any other indicator (Fig. 2). Also $\delta^{15} \mathrm{~N}$ values vary in a broad range throughout the profile with a weak trend of decreasing values towards the bottom of the core, but also do not seem to be related to the other indices under study (Supplement Table S3).

The depth distribution of the FTIR spectra of the KK peat core is given in Supplement Fig. S1. The distribution of FTIR band intensities can be roughly divided into two groups. Group I mainly reflects polysaccharides (bands $1053 \mathrm{~cm}^{-1}$ ) and show a slight decrease of values in the uppermost $38 \mathrm{~cm}$, whereas Group II includes aromatics (bands 1420, 1510, $1630 \mathrm{~cm}^{-1}$ ) and aliphatics (bands 2850, $2920 \mathrm{~cm}^{-1}$ ) and shows generally higher intensities in the upper $38 \mathrm{~cm}$. The humification index $\left(1630 / 1053 \mathrm{~cm}^{-1}\right)$ based on FTIR also greatly varies throughout the core (Fig. 2). Values are comparatively high in the upper $40 \mathrm{~cm}$ and show a distinct low between 38 and $50 \mathrm{~cm}$ depth. 


\subsubsection{Kleines Rotes Bruch (KRB)}

$\mathrm{C} / \mathrm{N}$ ratios in the KRB core exhibit a similar course as those found in the $\mathrm{KK}$ core. Values are higher in the top layer but decrease to minimum values between 5 and $10 \mathrm{~cm}$ (Fig. 3). From 10 to about $50 \mathrm{~cm} \mathrm{C/N}$ ratios steadily increase without larger changes and reach maximum values between 50 and $70 \mathrm{~cm}$. A remarkable sharp decrease of the $\mathrm{C} / \mathrm{N}$ ratios occurs between 65 and $70 \mathrm{~cm}$, also indicated by changes in the other decomposition proxies. Different from the KK profile, $\delta^{13} \mathrm{C}$ values in the KRB core do not exhibit a trend, but show intense changes throughout the core (Fig. 3). OI and $\mathrm{HI}$ indices show a distribution comparable to that observed in the KK profile. Again, lowest OI and highest HI values are observed in the upper $40 \mathrm{~cm}$ and the inverse course in the low part of the core interrupted by several short-term changes (Fig. 3). UV-ABS values do not show a trend as observed in KK. They are lowest in the surface layer and steadily increase down to about $30 \mathrm{~cm}$. Two pronounced maxima are observed between 30 and $45 \mathrm{~cm}$ and 65 to $70 \mathrm{~cm}$ where highest values occur (Fig. 3). No trend in $\delta^{15} \mathrm{~N}$ could be observed but there are intense changes especially in the upper $60 \mathrm{~cm}$ of the core. As for the KK site, in most sections, changes in $\delta^{15} \mathrm{~N}$ do not correspond to those of any other decomposition proxy (Fig. 3, see also Supplement Table S3).

FTIR band intensities of KRB peat (Supplement Fig. S2) show a similar distribution to those of KK peat. In the upper $45 \mathrm{~cm}$, with the exception of the uppermost $6 \mathrm{~cm}$ which reflects the living plants, bands indicative for aliphatics (2920, $\left.2860 \mathrm{~cm}^{-1}\right)$ and aromatics $\left(1630,1510,1420 \mathrm{~cm}^{-1}\right)$ show higher intensities than in deeper peat sections. The uppermost $50 \mathrm{~cm}$ are characterized by a minimum between 18 and $25 \mathrm{~cm}$ followed by a pronounced peak of the aliphatic and especially the aromatic bands $(25-35 \mathrm{~cm})$. Another peak of aliphatic and aromatic band intensities is found at $65 \mathrm{~cm}$. In contrast, bands indicating polysaccharides $\left(1053 \mathrm{~cm}^{-1}\right)$ show generally slightly higher values in the lower $50 \mathrm{~cm}$ and a trend of increasing values with depth. In some sections of the core, especially between 30 and $50 \mathrm{~cm}$, polysaccharide band intensities appear to develop inversely to the aliphatic and aromatic bands. High intensities of these bands are also found in the uppermost $\sim 10 \mathrm{~cm}$ where the high intensities of the polysaccharide band are attributed to the high cellulose and hemicellulose content in the living or only slightly decomposed plants. The development of the FTIR-based humification index with depth (Fig. 3) is also comparable to what is found in the KK core. Highest values are found in the upper $40 \mathrm{~cm}$ followed by a section of low values between 40 and $65 \mathrm{~cm}$ and a strong sharp increase up to maximum values between 65 and $70 \mathrm{~cm}$.

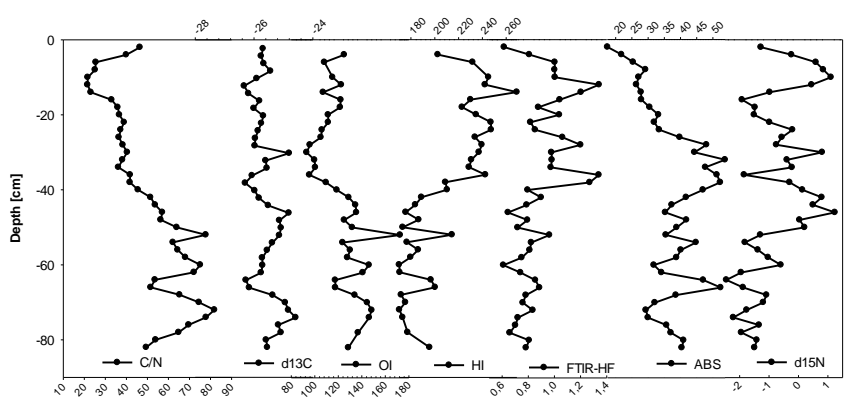

Figure 3. Records of decomposition proxies $\mathrm{C} / \mathrm{N}$ ratios, $\delta^{13} \mathrm{C}(\% \circ)$ in bulk peat, oxygen and hydrogen indices (OI, HI ( $\mathrm{mg} \mathrm{CO}_{2} \mathrm{~g}^{-1}$ TOC)) determined by Rock Eval ${ }^{\circledR}$ analyses, FTIR decomposition index $1630 / 1053 \mathrm{~cm}^{-1}$, UV-absorption of $\mathrm{NaOH}$ peatextracts and $\delta^{15} \mathrm{~N}(\% \circ)$ in bulk peat of the KRB core.

\section{Discussion}

\subsection{Interpretation of pyrolysis-GC-MS data and PCA (KK)}

The main difficulty with the interpretation of decomposition proxies in peat is the fact that changes in bog hydrology simultaneously affect the botanical composition, both causing changes in the relative abundance of polysaccharides, lignin and aliphatics. For example, in Sphagnum-dominated bogs a relatively high abundance of lignin indicates an increase of vascular plant species to the peat OM, as Sphagnum does not contain lignin. It also points to increased decomposition, as in peat polysaccharides are preferentially degraded (Bracewell et al., 1980; Benner et al., 1984; van der Heijden et al., 1990) causing a relative increase of lignin and/or aliphatics. Accordingly, drier conditions simultaneously result in an increase of vascular plant species and an increase of aerobic decomposition. A relatively high abundance of lignin may thus be used as a proxy for hydrological reconstructions. However, if the relative abundance of lignin and polysaccharides are used as either vegetation or decomposition proxy it is problematic to separate the two factors. To disentangle the relationship between changes in plant species distribution on one side and decomposition changes on the other we applied a factor analysis to all 82 quantified pyrolysis products of the KK core. To enable comparison with the decomposition proxies discussed below, they were included in the factor analysis. The first four factors explained $67.7 \%$ of the variance, of which the major part is explained by F1 and F2 $(51.7 \%)$.

The loadings of the F1-F2 projection (Fig. 4) roughly distinguish three groups of pyrolysis products. The markers of Sphagnum ( $\mathrm{Ph} 5, \mathrm{Ph} 7$ and $\mathrm{Ph} 9)$ and most polysaccharides show negative loadings on $\mathrm{F} 1$ and positive loadings on F2. This indicates a high contribution of Sphagnum moss, which mainly yields polysaccharides and (poly)phenolic compounds upon pyrolysis. Most lignin pyrolysis products 


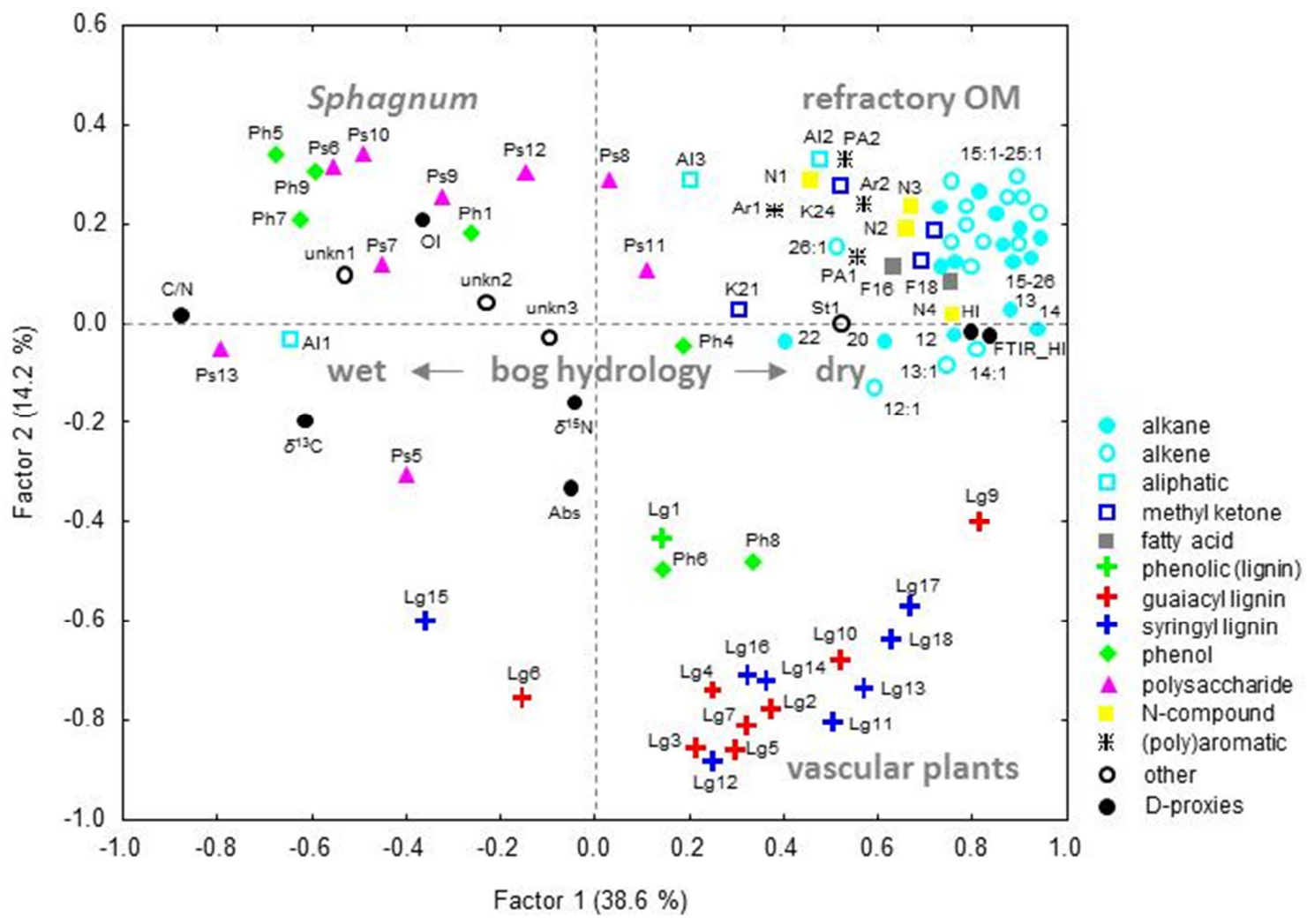

Figure 4. Factor loadings of the F1-F2 projection extracted from PCA of pyrolysis products from peat samples of the KK core. Note the opposite loadings of polysaccharides versus alkanes, alkenes and aliphatics on F1, while lignins have high loadings on F1 and F2 resulting in "fields" separating Sphagnum moss from vascular plants and refractory OM. Thus, the projection of F1-F2 factor loadings could help to separate decomposition and vegetation effects.

show negative loadings on F2 and positive loadings on F1 (Fig. 4); in Sphagnum-dominated peat this points towards an increased input of vascular plant species as mosses do not contain lignin. This possibility to differentiate between the contribution of Sphagnum and vascular plant residuals to the bulk peat is the particular value of the pyrolysis-GC-MS method. Aliphatics (except Al1), (poly)aromatics and nitrogen compounds show positive loadings on both F1 and F2 and indicate selective preservation and addition of microbial OM in peat (e.g. Schellekens et al., 2009).

The separation of polysaccharides, lignin and aliphatic pyrolysis products in $\mathrm{F} 1-\mathrm{F} 2$ projection suggests the following interpretation. F1 reflects the water table height at the time of plant death, with relatively dry conditions (positive on F1) causing an increase of vascular plants and aerobic decomposition. A lowering of the water table results in (i) a higher input of vascular plant material (negative on F2) and (ii) increased aerobic decomposition of Sphagnum moss (from negative on F1 to positive). F2 thus reflects the occurrence and degradation of vascular plants (lignin, negative on F2), which increases under relative dry conditions (positive loadings on F1). A more detailed look confirms this interpretation. The marker of lichens (Ph6) is located with the lignin pyrolysis products (Fig. 4), which confirms its preference for drier habitats (Kleinebecker et al., 2007). Both lignin moieties with an acetyl side chain $(\mathrm{Lg} 9, \mathrm{Lg} 17)$ show lowest loading on F2 and highest positive loading on F1 compared with other lignin pyrolysis products, which is in agreement with the oxygenation of lignin alkyl side chains upon degradation (Kögel-Knabner, 2002; Schellekens et al., 2012). The main pyrolysis product of cellulose is levoglucosan (Ps13) (Pouwels et al., 1987); its neutral loadings on F2 (Fig. 4) agree with the high abundance of cellulose in both mosses and vascular plants. Xylose, which has a high abundance in hemicelluloses of grasses (Smith and Harris, 1999; Wende and Fry, 1997) and sedges (Bourdon et al., 2000), results in 4-hydroxy-5,6-dihydro-(2H)-pyran-2-one (Ps5) upon pyrolysis (Pouwels et al., 1987); Ps5 is the only polysaccharide pyrolysis product that shows negative loadings on F2, which is in agreement with a graminoid origin and the high negative loadings of vascular plant derived lignins on F2. However, the overall contribution of this compound to the statistical interpretation is only low. 


\subsection{Comparison of decomposition proxies (KK, KRB)}

PCA of decomposition proxies reveals only minor differences if applied to the cores KK and KRB separately (Supplement Table S2). For both cores most of the variance (49 and $53.5 \%$ ) is explained by the first component. All used decomposition proxies show high loadings on the first component in both cores except $\delta^{15} \mathrm{~N}$ and UV-ABS, which both load significantly on a second component in the KRB core, and OI, which loads higher on the second component of the KK PCA. KK peat shows three components with higher loadings of OI and $\delta^{15} \mathrm{~N}$ on the second and high loadings of UV$\mathrm{ABS}$ on the third component. PCA gives two components if the data of both cores are analysed together, with $\mathrm{C} / \mathrm{N}$ ratios, HI, OI, FTIR and $\delta^{13} \mathrm{C}$ loading high on the first and UV-ABS and $\delta^{15} \mathrm{~N}$ on the second component.

From this it is likely that variations in all proxies, except of $\delta^{15} \mathrm{~N}$, are predominately attributed to changes in the degree of peat decomposition and in vegetation. The occurrence of the $\mathrm{C}$ and $\mathrm{N}$ isotope data in a second component can be explained by additional fractionation processes, which are independent of or only indirectly linked to decomposition such as changes in temperature, humidity, plant species or $\mathrm{N}$ recycling. This seems to be especially true for $\delta^{15} \mathrm{~N}$, which we assume is mostly influenced by $\mathrm{N}$-recycling, whereas $\delta^{13} \mathrm{C}$ appears to be mainly influenced by decomposition at least in the KRB core. This influence becomes more pronounced when the data of both cores are analysed together and significant loadings of $\delta^{13} \mathrm{C}$ disappear from the second component. The appearance of UV-ABS in a second or third component independent of the other proxies was unexpected as UV-ABS of $\mathrm{NaOH}$ extracts has been frequently used to determine the degree of peat humification. The missing correlation between UV-ABS and the other decomposition proxies indicates that changes in mass loss affecting $\mathrm{C} / \mathrm{N}$ ratios, FTIR band intensities, HI, OI and $\delta^{13} \mathrm{C}$ is not necessarily coincident with the formation of humic acids, the main process underlying changes in UV-ABS of $\mathrm{NaOH}$ peat extracts. However, changes in vegetation controlled by hydrology, i.e. shifts in vascular plant species (containing lignin) in peat which is dominated by Sphagnum (not containing lignin) during drier periods, may also lead to changes in the abundance of humic acids (Yeloff and Mauquoy, 2006; Chambers et al., 1997). Changes in humic acids may thus reflect more a signal of vegetation changes than of changes in humification or decomposition alone.

$\mathrm{C} / \mathrm{N}$ ratios and the FTIR humification index have been used in a number of studies as indicator of peat decomposition or, more exactly, as a measure of mass loss caused by increased mineralization during water table lows, although most studies do not consider changes in the botanical setting. The influence of plants on one hand and decomposition on the other is a key issue of this study. However, results from previous studies on trace element distribution in the same samples (Biester et al., 2012) show significant negative cor- relation between $\mathrm{C} / \mathrm{N}$ ratios and trace element (e.g. $\mathrm{Br}, \mathrm{Ti}$, $\mathrm{Zr}$ ) enrichment, confirming the major influence of mass loss on $\mathrm{C} / \mathrm{N}$ in peat dominated by Sphagnum. Thus, $\mathrm{C} / \mathrm{N}$ ratios in these Sphagnum-dominated cores predominantly indicate mass loss attributed to peat decomposition and to a lesser extent shifts in vegetation. While a number of studies address this shortcoming by analysing specific plant residues (e.g. remainders of Sphagnum only; Loisel et al., 2009; Skrzypek et al., 2007), this has not always been done and is not always possible in more decomposed peat or if Sphagnum provides only a small proportion of predominant vegetation.

$\mathrm{C} / \mathrm{N}$ ratios correlated well and negative with hydrogen indices in both cores $\left(r^{2}=0.74(\mathrm{KK}), r^{2}=0.74(\mathrm{KRB})\right)$, but only weakly with OI. The good correlation between $\mathrm{C} / \mathrm{N}$ and $\mathrm{HI}$ is explained by a concurrent loss of mass (decreasing $\mathrm{C} / \mathrm{N}$ ) during decomposition of labile compounds and a relative enrichment of aliphatics (increasing $\mathrm{HI}$ indices). The concept of peat humification/coalification suggests increasing decarboxylation under anoxic conditions. $\mathrm{C} / \mathrm{N}$ ratios, however, remain relatively stable under anoxic conditions and correlation between $\mathrm{C} / \mathrm{N}$ ratios and $\mathrm{OI}$ indices could therefore not be expected. The weak correlation between $\mathrm{C} / \mathrm{N}$ ratios and $\mathrm{OI}$ in our cores could be explained by oxidation of $\mathrm{OM}$ during low water tables, which does not generally lead to complete mineralization, but to an increase in carboxyl groups. Thus, dry falling may promote two processes: an increase in OM associated oxygen groups and losses of (oxygenated) OM through mineralization; thus mass loss and losses of oxygen from OM do not necessarily have to be correlated, suggesting that the HI may be a better indicator for decomposition than the OI.

Correlations of $\mathrm{C} / \mathrm{N}$ with intensities on FTIR band $1510 \mathrm{~cm}^{-1} \quad\left(r^{2}=0.69 ;\right.$ lignins, phenols $)$ and band $1630 \mathrm{~cm}^{-1}\left(r^{2}=0.52\right.$; lignins, other aromatics, aliphatic carboxylates) were always negative and significant, suggesting that lignins, aromatics and aliphatic carboxylates are enriched during peat mineralization (Fig. 5 and Supplement Table S3). However, correlations between $\mathrm{C} / \mathrm{N}$ ratios and pyrolysis products assigned to lignins or aromatics were significantly lower or absent, but, as will be discussed below, the intensities of the FTIR bands $1510 \mathrm{~cm}^{-1}$ and $1630 \mathrm{~cm}^{-1}$ are significantly correlated $\left(r^{2}=0.7\right.$ and $r^{2}=0.48$, respectively) with the first component (F1) obtained from the PCA of pyrolysis-GC-MS data (Fig. 5 and Supplement Table S3). As F1 is mostly determined by variations in concentrations of polysaccharides and aliphatics it is most likely that both bands mainly reflect changes in the content of aliphatics and to a lesser extent variations in aromatics or lignins. This may be due to an overlap of functional groups in the IR spectra (Coates, 2000), making an exact assignment of peaks difficult.

FTIR intensities indicating lipids and waxes (bands $2920 \mathrm{~cm}^{-1}$ and $2850 \mathrm{~cm}^{-1}$ ) do not correlate with any of the other decomposition proxies significantly, but show correlation with intensities of the bands $1630 \mathrm{~cm}^{-1}$ and $1420 \mathrm{~cm}^{-1}$ 

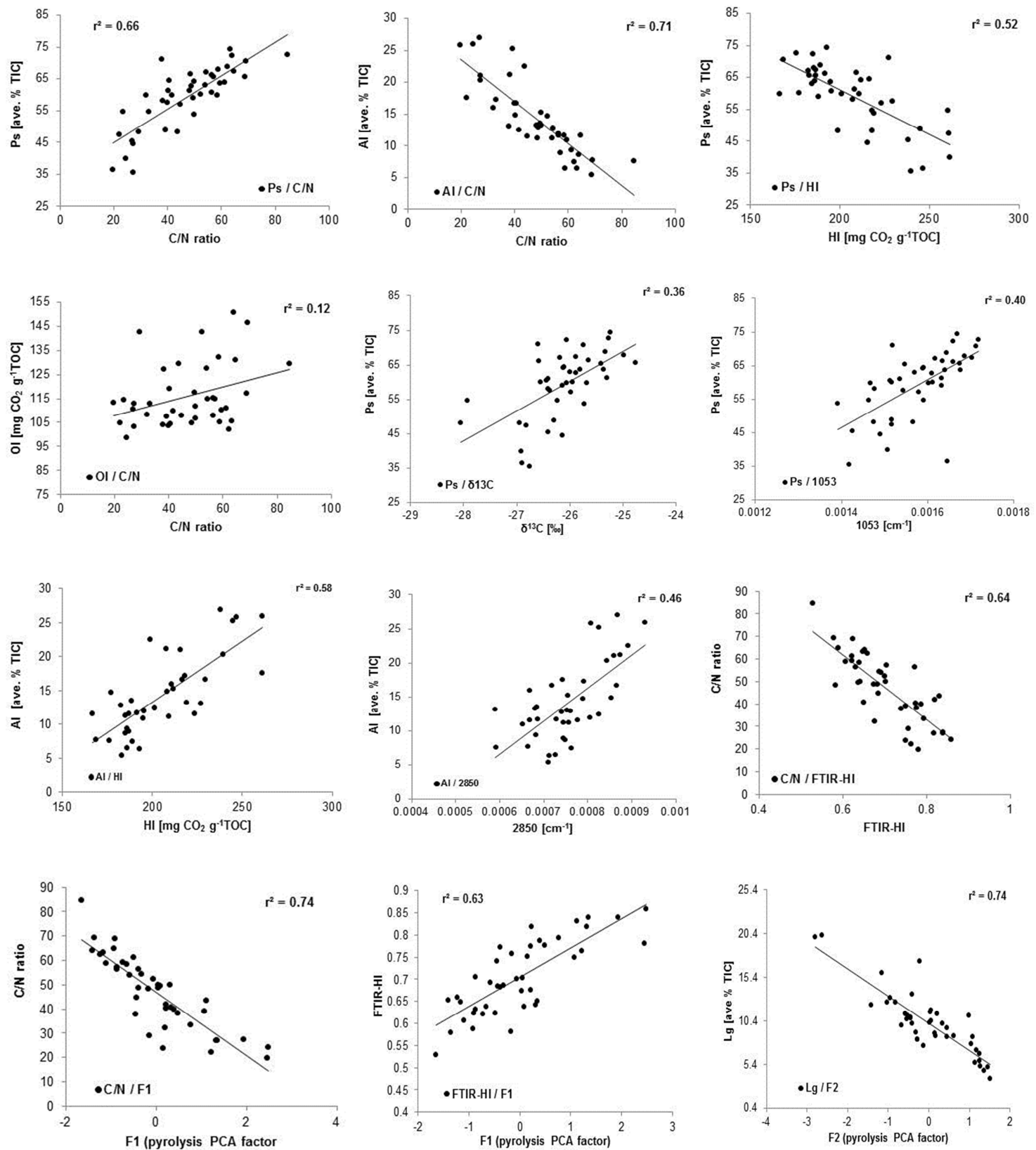

Figure 5. Selected correlations between decomposition proxies in the KK core and factors (F1, F2) obtained by PCA of pyrolysis-GC-MS data. $\mathrm{C} / \mathrm{N}$ ratios, FTIR bands $1053 \mathrm{~cm}^{-1}$ and $2850 \mathrm{~cm}^{-1}$, FTIR humification index (FTIR-HI, 1630/1053), HI and $\delta^{13} \mathrm{C}$ and molecular components determined by pyrolysis-GC-MS - polysaccharides (Ps), aliphatics (Al), lignin (Lg).

$\left(r^{2}=0.74\right.$ and 0.62 , respectively) which represent the group of lignins and other aromatics, as well as the FTIR humification index $(1630 / 1053)\left(r^{2}=0.65\right)$ (Supplement Table S3). This probably indicates that the bands $2920 \mathrm{~cm}^{-1}$ and $2850 \mathrm{~cm}^{-1}$ do not solely absorb on fats and waxes as suggested previously (Cocozza et al., 2003; Niemeyer et al., 1992) but overlap with signals from polysaccharides and cellulose (Coates, 2000). HI solely correlate significantly with aromatics and lignin (band $1510 \mathrm{~cm}^{-1}$ not shown) and
F1 $\left(r^{2}=0.6\right)$ and the FTIR humification index $\left(r^{2}=0.48\right)$ which indicates that both aliphatics and aromatics increase during decomposition owing to the loss of polysaccharides and both increase HI values. Such ambiguous information from FTIR data suggests that interpretation needs to be done with caution. 


\subsection{Comparison of decomposition proxies and molecular components (KK)}

PCA of the pyrolysis-GC-MS data shows that the hydrological controlled distribution of polysaccharides on one side and aliphatics and lignins on the other determine the variability in the molecular peat components through peat decomposition. Comparison of the decomposition proxies derived from $\mathrm{KK}$ peat with the molecular compounds obtained by pyrolysisGC-MS (Fig. 4 and Supplement Fig. S3) indicates that factor $\mathrm{F} 1$ and the group of aliphatics yield similar records as the hydrogen index and the FTIR-humification index. $\mathrm{C} / \mathrm{N}$ ratios, $\delta^{13} \mathrm{C}$ and the oxygen index show similarity to the record of polysaccharides, which runs inversely to the PCA factor F1 (Supplement Fig. S3). Under drier conditions, decomposition through mineralization of predominately polysaccharides is thus higher, but so also is the abundance of vascular plants, which causes an increase in lignins, $\mathrm{HI}$ values and a decrease of polysaccharides, $\mathrm{C} / \mathrm{N}$ ratios, $\delta^{13} \mathrm{C}$ and $\mathrm{OI}$ values. Accordingly, wet conditions are indicated by the reverse trend in the distribution of the proxies attributed to higher abundance of Sphagnum in relation to lignin-containing graminoids and less intense decomposition of polysaccharides (Fig. 4).

\subsection{1 $\mathrm{C} / \mathrm{N}$ ratios}

In detail, $\mathrm{F} 1$ is negatively correlated with the $\mathrm{C} / \mathrm{N}$ ratio $\left(r^{2}=\right.$ 0.74; Fig. 5, Supplement Table S2) and positively correlated with polysaccharides $\left(r^{2}=0.66\right.$; Table 2$)$, which means that - not surprisingly - a higher content of polysaccharides correlates with a lower degree of peat decomposition. However, the $\mathrm{C} / \mathrm{N}$ ratio is similarly affected by the effects of both botanical changes and aerobic decomposition upon changes in hydrology. The $\mathrm{C} / \mathrm{N}$ ratio decreases with decomposition but also highly differs between Sphagnum spp. and vascular plants (e.g. Hornibrook et al., 2000). Table 1 shows slightly higher $\mathrm{C} / \mathrm{N}$ ratios for the analysed Sphagnum species compared to graminoids and ericoids. However, $\mathrm{C} / \mathrm{N}$ ratios in Sphagnum from the Harz sites (Table 1) are much lower than those in Sphagnum from remote sites (Schmidt et al., 2010), which is most likely a result of the high atmospheric $\mathrm{N}$ deposition in the Harz Mountains in the past decades. As large parts of atmospheric $\mathrm{N}$ are captured by Sphagnum moss (Heijmans et al., 2002). Sphagnum from before the 20th century is likely to show similar $\mathrm{C} / \mathrm{N}$ ratios to those from presentday remote sites (see e.g. $\mathrm{C} / \mathrm{N}$ of 89-134 reported in Broder et al., 2012). Independently of the initial $\mathrm{C} / \mathrm{N}$ ratio in the upper part, the highest negative loading of $\mathrm{C} / \mathrm{N}$ on $\mathrm{F} 1$ and the loading of almost zero on F2 (Fig. 4) indicate that despite light shifts in vegetation, $\mathrm{C} / \mathrm{N}$ ratios here provide a reasonable estimate of the degree of decomposition. In a peat record from Tierra del Fuego major shifts in $\mathrm{C} / \mathrm{N}$ ratio perfectly agreed with the main botanical transitions, from Sphagnumdominated to Sphagnum-Juncus to Juncus-dominated peat (Schellekens and Buurman, 2011). In another peat record
Table 2. Groups of pyrolysis products in peat samples of KK.

\begin{tabular}{lrl}
\hline Group & Avg $\%^{\mathrm{a}}$ & $\mathrm{SD}^{\mathrm{b}}$ \\
\hline Polysaccharides & 59.2 & 9.76 \\
Aliphatics & 14.1 & 5.61 \\
Lignins & 10.1 & 3.63 \\
Phenols & 8.6 & 2.68 \\
Aromatics & 5.3 & 4.01 \\
N-compounds & 2.1 & 1.55 \\
Other & 0.3 & 0.34 \\
Polyaromatics & 0.2 & 0.06 \\
\hline
\end{tabular}

a Mean value for bulk sample relative to the sum

of all quantified pyrolysis products $(n=42)$.

b Standard deviation.

dominated by graminoids, an increase in lignin and aliphatics was related to decomposition (Schellekens et al., 2011; Schellekens et al., 2012), but no correlation with $\mathrm{C} / \mathrm{N}$ ratio was found. However, within the KK peat, which is dominated by Sphagnum, shifts in $\mathrm{C} / \mathrm{N}$ ratio mainly reflect decomposition. The fact that not lignin (indicating vascular plants) but aliphatics showed the better correlation with $\mathrm{C} / \mathrm{N}$ ratios ( $r^{2}=0.60$; Fig. 5, Supplement Table S2) further confirms this. Because vascular plants increase under relatively dry conditions in Sphagnum-dominated peat, this automatically indicates a higher degree of aerobic decomposition (positive loadings of lignin on F1, Fig. 4). A combination of vegetation and decomposition proxies is expected to best reflect changes in bog hydrology, as vegetation shifts are probably slower than decomposition (which is a continuous process). On the other hand secondary decomposition may disturb the hydrological interpretation when only decomposition proxies are used.

\subsubsection{FTIR}

Several bands of FTIR intensities show significant correlation with factor F1 of the pyrolysis-GC-MS data (Fig. 5, Supplement Table S3, see also Supplement Fig. S4 for depth profiles). Best correlation was found between the bands 1510 and 1630 (aromatic structures in lignins or aliphatic carboxylates) and F1. Positive correlation with F1 was found for the bands $2920\left(r^{2}=0.5\right), 2850\left(r^{2}=\right.$ $0.57)$ (aliphatic structures) and $1420\left(r^{2}=0.55\right)$ (carboxylate structures), which was even higher if these bands were correlated to aliphatics, the major components behind F1 (Supplement Table S3). Negative correlations with F1 were found for the bands $891\left(r^{2}=0.73\right), 1151\left(r^{2}=\right.$ $0.58)$ and $1053\left(r^{2}=0.36\right)$ (polysaccharides), which were slightly weaker if directly correlated to aliphatics (negative) or polysaccharides (positive) determined by pyrolysisGC-MS (Supplement Table S3). Significant correlation between the group of lignins determined by pyrolysis-GCMS and FTIR-bands specific for lignin components (mainly phenolic and aromatic structures) could not be found. This 
could be related to the fact that also Sphagnum contains high amounts of lignin-like phenolic compounds. Comparable to what has been found by pyrolysis-GC/MS, intensity changes of the FTIR bands mainly reflect the changes in the peat's concentrations of aliphatic and aromatic structural components and polysaccharides (Supplement Fig. S4), while signals for lignin may be influenced by too much overlapping with other functional groups. Nevertheless, ratios of intensities on band 1630 (aromatic structures in lignins or aliphatic carboxylates) and those of band 1053 (0.36) (polysaccharides), which has been suggested as a FTIR humification index, are significantly correlated to F1 $\left(r^{2}=\right.$ $0.67)$ (Fig. 5), aliphatics $\left(r^{2}=0.58\right)$, polysaccharides $\left(r^{2}=\right.$ $0.55)$, 4-isopropenylphenol $\left(r^{2}=0.48\right)$ (Sphagnum) and a sesquiterpene (Pinus) $\left(r^{2}=0.43\right)$ (Supplement Table S3). A unique interpretation of the FTIR bands is obviously constrained by their overlap in complex OM such as peat, a shortcoming which may only partly be resolved by relating FTIR-based indices to molecular markers. FTIR data, however, confirm the interpretation that decomposition on a molecular level in the KK peat record is mainly indicated by an increase in aliphatics and aromatic structures and a decrease in polysaccharides.

\subsubsection{Oxygen and hydrogen indices (OI, HI)}

The oxygen/carbon ratio in peat as expressed by the OI is expected to be high in sections where decomposition is low and higher amounts of oxygen containing compounds occur (e.g. polysaccharides). According to the van Krevelen concept of coal petrology the oxygen index is expected to decrease during proceeding OM decomposition and coalification (Tissot and Welte, 1978). Although the OI index showed high values during the Sphagnum-dominated period (38-48 cm, Figs. 1 and 3 (4-isopropenylphenol)) and also in the uppermost sample, correlations with other pyrolysis-GCMS proxies were rather low (Supplement Table S3). Significant correlation $\left(r^{2}=0.41\right)$ was only found for an unidentified polysaccharide (Ps10, Supplement Table S1) and for 4-isopropenylphenol, the latter which is specific for Sphagnum. Higher values of $\mathrm{HI}$ (equivalent to high $\mathrm{H} / \mathrm{C}$ ) in peat deposits have been interpreted as hydrogen-rich labile $\mathrm{C}$ compounds in unprocessed OM (Outridge and Sanei, 2010). However, the HI index is thought to reflect aliphatic structures in general and the HI record of KK peat was positively correlated $\left(r^{2}=0.49\right)$ with aliphatics determined by Py-GC-MS and with FTIR band 460 (aliphatics) $\left(r^{2}=0.58\right.$ ) (not shown), but only weak $\left(r^{2}=0.32\right.$ and 0.26$)$ if correlated to the bands $2850 \mathrm{~cm}^{-1}$ and $2920 \mathrm{~cm}^{-1}$, respectively (lipids, waxes, $\mathrm{CH}_{2}$ stretching $\left(2850 \mathrm{~cm}^{-1}\right)$ (Supplement Table S3). Negative, but higher correlation $\left(r^{2}=0.58\right)$ was found with band $891 \mathrm{~cm}^{-1}$ indicative of polysaccharides. Thus, the HI record in KK peat also reflects the relative enrichment of aliphatics compared to more labile polysaccharides such as cellulose as we have already concluded from the results of pyrolysis-GC-MS measurements. The H/C ratio is often found to decrease with burial depth and regarded to reflect a maturity-enhanced conversion of aliphatic $\mathrm{C}$ to fixed aromatic $\mathrm{C}$ under Rock Eval conditions (Schenk et al., 1986). However, such assumptions seem not to hold true for peats with a low diagenetic grade, in which decomposition of polysaccharides results in a relative increase of aliphatics. A transformation to aromatic compounds seems hardly relevant, which would explain the absence of a correlation between $\mathrm{HI}$ and aromatics and only a weak correlation between $\mathrm{HI}$ and polyaromatics in KK peat.

\subsection{4 $\mathrm{C}$ and $\mathrm{N}$ isotope ratios $\left(\delta^{13} \mathrm{C}, \delta^{15} \mathrm{~N}\right)$}

In the literature information derived from $\delta^{13} \mathrm{C}$ values in peat are interpreted in different ways. $\mathrm{C}$ isotopes in peat have been assigned to several processes, among which are the inherent isotopic signals of the plants owing to e.g. the photosynthesis pathway, the temperature during plant formation at the bog's surface, bog surface wetness and by decomposition processes. Jedrysek and Skrzypek (2005) stated that peat diagenesis has generally no influence on $\delta^{13} \mathrm{C}$ in Sphagnum or extracted cellulose. Kaislahti et al. (2010) reported a dependency of $\delta^{13} \mathrm{C}$ in young peat on temperature and could also not find a relationship with peat decomposition patterns. Several studies have stated that Sphagnum $\delta^{13} \mathrm{C}$ reflects surface moisture conditions (Rice and Giles, 1996; Price et al., 1997; Ménot and Burns, 2001; Loisel et al., 2009). While some studies found that $\delta^{13} \mathrm{C}$ values were lower during drier conditions (Loisel et al., 2009) or in more decomposed peat (Broder et al., 2012), the opposite effect was also reported (Hong et al., 2001). Nevertheless, this indicates that $\mathrm{C}$ isotope ratios may indeed be influenced by decomposition processes. Several publications indicate a decrease in $\delta^{13} \mathrm{C}$ due to preferential preservation of refractory $\mathrm{C}$ compounds depleted in ${ }^{13} \mathrm{C}$ (Akagi et al., 2004; Melillo et al., 1989), but uniform depth trends with no significant $C$ isotope fraction or fractionation effects during $\mathrm{CH}_{4}$ formation were also observed (Clymo and Bryant, 2008; Kracht and Gleixner, 2000). However, only very few studies have included analyses of peat decomposition or molecular proxies, so that the role of peat decomposition on $\mathrm{C}$ isotopes often remains speculative. Values of $\delta^{13} \mathrm{C}$ in peat from the $\mathrm{KK}$ bog range between -24.76 and $-28.06 \%$ with a median of $-26.1 \%$, which is typical for C3 plants (Hong et al., 2001), but slightly heavier than the peat-forming plants of the Harz mires $(-27.42$ to $-29.06 \%$ o) (Table 1). Correlations of the $\delta^{13} \mathrm{C}$ record with pyrolysis-GC/MS molecular components are comparatively weak (Supplement Table S3). Levoclucosan, a pyrolysis product of cellulose, as well as the group of polysaccharides show a positive correlation of $r^{2}=0.41$ and $r^{2}=0.37$, respectively. Best correlation was found with aliphatics $\left(r^{2}=0.59\right.$, negative), which means that $\delta^{13} \mathrm{C}$ becomes lighter with the enrichment of aliphatics. Moreover, an increase in lignin content during water table lows as a 
result of an absolute increase in vascular plants and a relative decrease of polysaccharides might also lower $\delta^{13} \mathrm{C}$ values, although no correlation between lignin and $\delta^{13} \mathrm{C}$ has been found. The unusually low $\delta^{13} \mathrm{C}$ in the surface layer is probably attributed to the present-day increase in grasses on the bog's surface or the "Suess" effect, which has caused a decrease in the global atmospheric $\delta^{13} \mathrm{C}$ value from -6.5 to $-8.0 \%$ since the Industrial Revolution (Francey et al., 1995).

Values of $\delta^{15} \mathrm{~N}$ are not correlated with any of the pyrolysisGC-MS components or FTIR band intensities (Supplement Table S3). As an essential nutrient, nitrogen undergoes intense recycling, which most likely is accompanied by intense isotope fractionation processes (Robinson, 2001). Moreover, $\mathrm{N}$ isotope variability in different peat-forming plants will further add to the overall high variability, so that fractionation attributed to peat decomposition seems to have a minor effect, and thus is mostly overwritten by other fractionation processes, especially $\mathrm{N}$ recycling. $\delta^{15} \mathrm{~N}$ values in the Harz mire's plants (Table 1) were in agreement with other studies on peatland plants (Asada et al., 2005) and were significantly lower than those found in peat (mean $-1.23 \%$, KK; and $0.75 \%$, KRB) indicating that microbial processes, especially denitrification, have removed isotopic light $\mathrm{N}$ components from the peat (Jones et al., 2010). Ericoids (C. vulgaris) were typically low in ${ }^{15} \mathrm{~N}(-8.13 \%)$ due to their association with mycorrhiza (Gebauer and Dietrich, 1993), but this signal is not reflected in the peat owing to inverse enrichment of ${ }^{13} \mathrm{C}$ in the remaining fungal tissues. The reverse behaviour of ${ }^{15} \mathrm{~N}$ with the other proxies in the part where Sphagnum dominated and lowest decomposition took place $(38-45 \mathrm{~cm})$ suggests that when Sphagnum is dominant the effect of vegetation is larger than that of decomposition, which was also found for $\mathrm{C} / \mathrm{N}$ ratio.

\subsubsection{UV-ABS}

Despite some similarities in the records of UV-ABS values and F1 and aliphatics especially below $25 \mathrm{~cm}$, absorption data showed no significant correlations with other molecular components or decomposition indices (Supplement Table S3). However, low absorption values in the upper three samples and in the Sphagnum-dominated period between 38 and $48 \mathrm{~cm}$ agreed with a low degree of decomposition of recent samples and during Sphagnum dominance (Figs. 2 and 3 and Supplement Fig. S3). The absence of good correlations with other proxies can be attributed to the fact that the peat, although dominated by Sphagnum, had a relatively high contribution and high variability of vascular plant species that differ in chemical composition and chemical changes during decay (e.g. graminoids, ericoids, pine, etc.) (Baumann, 2009). UV-ABS of alkaline peat extracts is based on the assumption that more extractable humic acids indicate a higher degree of peat decomposition, but the conditions under which increased "humification" occurs are poorly defined. More- over, the molecular compounds extracted by alkaline leaching are loosely specified, although it is believed that mostly aromatic moieties such as lignin or phenols are preferentially extracted. However, lignins and aromatics in KK peat have been found not to be correlated to any of the decomposition proxies including the UV-ABS values and the reasons for this lack of significant correlation remains largely unresolved.

\section{Conclusions}

The two investigated peat cores show similar progression and relationship of decomposition proxies indicating that the observed changes are attributed to external and at least regional forcing. Results from PCA reveal high correlation between $\mathrm{C} / \mathrm{N}$, HI and the FTIR-humification index and moderate correlation with $\delta^{13} \mathrm{C}$ and OI. Accordingly, all investigated proxies show changes upon peat decomposition reflecting changes in mass loss and related relative enrichment of more persistent components. Pyrolysis-GC-MS analyses of the KK core have shown that preferential decomposition of polysaccharides and relative enrichment of aliphatics, as indicated by the decomposition proxies, is predominantly caused by decomposition instead of vegetation changes. Although lignins are also enriched during peat decay their influence on decomposition patterns are of less importance, here. Going hand in hand during water table changes, peat decomposition appears to overwrite most of the influence of changes in the contribution of vascular plants in the Harz mires and thus allows the use of $\mathrm{C} / \mathrm{N}$ ratio, FTIR index and the HI as bulk decomposition proxies. But in order to understand the processes and to ensure consistency of decomposition proxies, comparison of proxies that provide detailed molecular information (i.e. analytical pyrolysis) is recommended.

Despite minor botanical changes, $\mathrm{C} / \mathrm{N}$ ratios in the Harz peats reliably reflected changes in bog hydrology and mass loss during aerobic decomposition. Hydrogen indices appear to be mainly dependent on the preferential mineralization of polysaccharides and the enrichment of aliphatics, whereas oxygen indices are assumed to be additionally influenced by oxidative input of oxygen functional moieties during aerobic peat decay. FTIR bands give extensive information on the abundance of major groups of organic components and provide a broad picture of qualitative and quantitative changes in the OM structure during decomposition, although being constrained by overlap of defined bands of functional units. The FTIR humification index most reliably reflects peat decomposition in the Harz cores. Values of $\delta^{13} \mathrm{C}$ in bulk peat show intense changes with a clear trend towards high values with depth and significant correlation with $\mathrm{C} / \mathrm{N}$ ratios, which hints at an influence of decomposition processes probably due to selective enrichment of isotopically lighter compounds such as lignins. The strong variation of $\delta^{15} \mathrm{~N}$ values and the absence of any correlation with peat decomposition proxies suggest that variations in $\delta^{15} \mathrm{~N}$ are mainly controlled 
by $\mathrm{N}$ recycling and plant uptake in the acrotelm, and to a low extent by peat decomposition. Although UV-ABS is frequently used as a measure of humification, its correlation with other decomposition proxies in the KK peat record was generally low. One reason might be that the impact of decomposition on the formation of humic acids is poorly constrained and the results obtained are chemically poorly defined.

$\mathrm{C} / \mathrm{N}$ ratios, pyrolysis-GC-MS, and FTIR spectroscopy yielded a comprehensive picture of mass loss and the relative abundance of different OM components (e.g. carbohydrates versus aliphatics), respectively, during peat decomposition at the investigated sites. Future studies need to show to what extent these results can be generalized for other sites and how decomposition proxies compare at sites with different botanical, hydrological or climatic background.

\section{The Supplement related to this article is available online at doi:10.5194/bg-11-2691-2014-supplement.}

Acknowledgements. The authors like to thank Adelina Calean and Petra Schmidt at Technische Universität Braunschweig for their help with geochemical analyses. Stable isotope measurements were done in the Isotope Biogeochemistry Lab at BayCEER, headed by G. Gebauer. The help of Heidi Zier with FTIR analysis and the laboratory staff at the Department of Hydrology (headed by S. Peiffer), University of Bayreuth, is greatly acknowledged. This research was also supported by the collaboration framework of projects CGL2010-20672 and 10PXIB200182PR (Spanish Ministry of Science and Innovation, General Directorate of I+D-Xunta de Galicia).

Edited by: D. Obrist

\section{References}

Aaby, B. and Tauber, H.: Rates of peat formation in relation to degree of humification and local environment, as shown by studies of a raised bog in denmark, Boreas, 4, 1-17, 1975.

Akagi, T., Minomo, K., Kasuya, N., and Nakamura, T.: Variation in carbon isotopes of bog peat in the ozegahara peatland, japan, Geochem. J. Japan, 38, 299-306, 2004.

Artz, R. R. E., Chapman, S. J., Jean Robertson, A. H., Potts, J. M., Laggoun-Défarge, F., Gogo, S., Comont, L., Disnar, J.-R., and Francez, A.-J.: Ftir spectroscopy can be used as a screening tool for organic matter quality in regenerating cutover peatlands, Soil Biol. Biochem., 40, 515-527, 2008.

Asada, T., Warner, B. G., and Aravena, R.: Nitrogen isotope signature variability in plant species from open peatland, Aquat. Bot., 82, 297-307, doi:10.1016/j.aquabot.2005.05.005, 2005.

Bahnson, H.: Kolorimetriske bestemmelse af humificenngstal i hojmosetorv fra fuglso mose på djursland, Meddelande Dansk Geologisk Forening, 18, 55-63, 1968.
Barber, K. E.: Peatland records of holocene climate change, Encyclopedia of Quaternary Science, 1883-1894, 2006.

Barber, K. E. and Langdon, P. G.: What drives the peat-based palaeoclimate record? A critical test using multi-proxy climate records from northern britain, Quaternary Sci. Rev., 26, 33183327, 2007.

Baumann, K.: Entwicklung der moorvegetation im nationalpark harz, in: Schriftenreihe aus dem nationalpark harz, Nationalparkverwaltung Harz, Wernigerode, 2009.

Benner, R., Maccubbin, A. E., and Hodson, R. E.: Anaerobic biodegradation of the lignin and polysaccharide components of lignocellulose and synthetic lignin by sediment microflora, Appl. Environ. Microbiol., 47, 998-1004, 1984.

Benner, R., Fogel, M. L., Sprague, E. K., and Hodson, R. E.: Depletion of $\mathrm{c}$ in lignin and its implications for stable carbon isotope studies, Nature, 329, 708-710, 1987.

Biester, H., Martinez-Cortizas, A., Birkenstock, S., and Kilian, R.: Effect of peat decomposition and mass loss on historic mercury records in peat bogs from patagonia, Environ. Sci. Technol., 37, 32-39, 2003.

Biester, H., Keppler, F., Putschew, A., Martinez-Cortizas, A., and Petri, M.: Halogen retention, organohalogens, and the role of organic matter decomposition on halogen enrichment in two chilean peat bogs, Environ. Sci. Technol., 38, 1984-1991, 2004.

Biester, H., Bindler, R., Martinez-Cortizas, A., and Engstrom, D. R.: Modeling the past atmospheric deposition of mercury using natural archives, Environ. Sci. Technol., 41, 4851-4860, 2007.

Biester, H., Hermanns, Y.-M., and Martinez Cortizas, A.: The influence of organic matter decay on the distribution of major and trace elements in ombrotrophic mires - a case study from the harz mountains, Geochim. Cosmochim. Ac., 84, 126-136, 2012.

Blackford, J. J. and Chambers, F. M.: Determining the degree of peat decomposition for peat-based palaeoclimatic studies, Int. Peat J., 5, 7-24, 1993.

Boon, J. J., Dupont, L., and De Leeuw, J. W.: Characterization of a peat bog profile by curie-point pyrolysis-mass spectrometry combined with multivariant analysis and by pyrolysis-mass spectrometry, Peat Water, 215-239, 1986.

Booth, R. K.: Testing the climate sensitivity of peat-based paleoclimate reconstructions in mid-continental north america, Quaternary Sci. Rev., 29, 720-731, 2010.

Borgmark, A. and Schoning, K.: A comparative study of peat proxies from two eastern central swedish bogs and their relation to meteorological data, J. Quaternary Sci., 21, 109-114, 2006.

Bourdon, S., Laggoun-Défarge, F., Disnar, J.-R., Maman, O., Guillet, B., Derenne, S., and Largeau, C.: Organic matter sources and early diagenetic degradation in a tropical peaty marsh (tritrivakely, madagascar). Implications for environmental reconstruction during the sub-atlantic, Org. Geochem., 31, 421-438, 2000.

Bracewell, J. M., Robertson, G. W., and Williams, B. L.: Pyrolysismass spectrometry studies of humification in a peat and a peaty podzol, J. Anal. Appl. Pyrol., 2, 53-62, 1980.

Broder, T., Blodau, C., Biester, H., and Knorr, K. H.: Peat decomposition records in three pristine ombrotrophic bogs in southern Patagonia, Biogeosciences, 9, 1479-1491, doi:10.5194/bg9-1479-2012, 2012.

Buurman, P., Nierop, K. G. J., Pontevedra Pombal, X., and Martínez Cortizas, A.: Molecular chemistry by pyrolysis-gc/ms of selected 
samples of the penido vello peat deposit, nw spain, Peatlands, Evolution and Records of Environmental and Climate Changes, 217-240, 2006.

Carrie, J., Sanei, H., and Stern, G.: Standardisation of rock-eval pyrolysis for the analysis of recent sediments and soils, Org. Geochem., 46, 38-53, 2012.

Chambers, F. M., Barber, K. E., Maddy, D., and Brew, J.: A 5500year proxy-climate and vegetation record from blanket mire at talla moss, borders, scotland, Holocene, 7, 391-399, 1997.

Chambers, F. M., Beilman, D. W., and Yu, Z.: Methods for determining peat humification and for quantifying peat bulk density, organic matter and carbon content for palaeostudies of climate and peatland carbon dynamics, Mires Peat, 7, 1-10, 2011.

Chambers, F. M., Booth, R. K., De Vleeschouwer, F., Lamentowicz, M., Le Roux, G., Mauquoy, D., Nichols, J. E., and van Geel, B.: Development and refinement of proxy-climate indicators from peats, Quatern. Int., 268, 21-33, 2012.

Charman, D. J., Hendon, D., and Packman, S.: Multiproxy surface wetness records from replicate cores on an ombrotrophic mire: Implications for holocene palaeoclimate records, J. Quaternary Sci., 14, 451-463, 1999.

Charman, D. J., Blundell, A., Chiverrell, R. C., Hendon, D., and Langdon, P. G.: Compilation of non-annually resolved holocene proxy climate records: Stacked holocene peatland palaeo-water table reconstructions from northern britain, Quaternary Sci. Rev., 25, 336-350, 2006.

Charman, D. J., Barber, K. E., Blaauw, M., Langdon, P. G., Mauquoy, D., Daley, T. J., Hughes, P. D. M., and Karofeld, E.: Climate drivers for peatland palaeoclimate records, Quaternary Sci. Rev., 28, 1811-1819, 2009.

Clymo, R. S.: The limits to peat bog growth, Philos. T. R. Soc.-B, 303, 605-654, 1984.

Clymo, R. S. and Bryant, C. L.: Diffusion and mass flow of dissolved carbon dioxide, methane, and dissolved organic carbon in a 7-m deep raised peat bog, Geochim. Cosmochim. Ac., 72, 2048-2066, 2008.

Coates, J.: Interpretation of infrared spectra, a practical approach, in: Encyclopedia of analytical chemistry, edited by: Meyers, R. A., John Wiley \& Sons Ltd., Chichester, 10815-10837, 2000.

Cocozza, C., D’Orazio, V., Miano, T. M., and Shotyk, W.: Characterization of solid and aqueous phases of a peat bog profile using molecular fluorescence spectroscopy, esr and ft-ir, and comparison with physical properties, Org. Geochem., 34, 49-60, 2003.

Disnar, J.-R., Jacob, J., Morched-Issa, M., Lottier, N., and Arnaud, F.: Assessment of peat quality by molecular and bulk geochemical analysis: Application to the holocene record of the chautagne marsh (haute savoie, france), Chem. Geol., 254, 101-112, 2008.

Eriksson, L., Johansson, E., Kettaneh-Wold, N., and Wold, S.: Introduction to multi- and megavariate data analysis using projection methods (pca \& pls), edited by: Eriksson, L., Johansson, E., and Kettapeh-Wold, S., Umetrics, 1999.

Francey, R., Tans, P., Allison, C., Enting, I., White, J., and Trolier, M.: Changes in oceanic and terrestrial carbon uptake since 1982, 1995.

Gebauer, G. and Dietrich, P.: Nitrogen isotope ratios in different compartments of a mixed stand of spruce, larch and beech trees and of understorey vegetation including fungi, Isotopenpraxis, 29, 35-44, doi:10.1080/10256019308046133, 1993.
González, J. A., González-Vila, F. J., Almendros, G., Zancada, M. C., Polvillo, O., and Martín, F.: Preferential accumulation of selectively preserved biomacromolecules in the humus fractions from a peat deposit as seen by analytical pyrolysis and spectroscopic techniques, J. Anal. Appl. Pyrol., 68-69, 287-298, 2003.

Halma, G., Van Dam, D., Haverkamp, J., Windig, W., and Meuzelaar, H. L. C.: Characterization of an oligotrophic-eutrophic peat sequence by pyrolysis-mass spectrometry and conventional analysis methods, J. Anal. Appl. Pyrol., 7, 167-183, 1984.

Heijmans, M. M. P. D., Klees, H., De Visser, W., and Berendse, F.: Effects of increased nitrogen deposition on the distribution of ${ }^{15} \mathrm{~N}$-labeled nitrogen between sphagnum and vascular plants, Ecosystems, 5, 500-508, 2002.

Hendon, D., Charman, D. J., and Kent, M.: Palaeohydrological records derived from testate amoebae analysis from peatlands in northern england: Within-site variability, between-site comparability and palaeoclimatic implications, Holocene, 11, 127-148, 2001.

Holmgren, A. and Norden, B.: Characterization of peat samples by diffuse reflectance ft-ir spectroscopy, Appl. Spectrosc., 42, 255262, 1988.

Hong, Y. T., Wang, Z. G., Jiang, H. B., Lin, Q. H., Hong, B., Zhu, Y. X., Wang, Y., Xu, L. S., Leng, X. T., and Li, H. D.: A 6000year record of changes in drought and precipitation in northeastern china based on a $\delta 13 \mathrm{c}$ time series from peat cellulose, Earth Planet. Sci. Lett., 185, 111-119, 2001.

Hornibrook, E. R. C., Longstaffe, F. J., Fyfe, W. S., and Bloom, Y.: Carbon-isotope ratios and carbon, nitrogen and sulfur abundances in flora and soil organic matter from a temperate-zone bog and marsh, Geochem. J., 34, 237-245, 2000.

Ise, T., Dunn, A. L., Wofsy, S. C., and Moorcroft, P. R.: High sensitivity of peat decomposition to climate change through watertable feedback, Nat. Geosci., 1, 763-766, 2008.

Jedrysek, M.-O. and Skrzypek, G.: Hydrogen, carbon and sulphur isotope ratios in peat: The role of diagenessis and water regimes in reconstruction of past climates, Environ. Chem. Lett., 2, 179183, 2005.

Jones, M. C., Peteet, D. M., and Sambrotto, R.: Late-glacial and holocene $\delta^{15} \mathrm{n}$ and $\delta^{13} \mathrm{c}$ variation from a kenai peninsula, alaska peatland, Palaeogeogr. Palaeocl., 293, 132-143, 2010.

Kaal, J., Baldock, J. A., Buurman, P., Nierop, K. G. J., PontevedraPombal, X., and Martínez-Cortizas, A.: Evaluating pyrolysisGC/MS and ${ }^{13} \mathrm{C}$ CPMAS NMR in conjunction with a molecular mixing model of the Penido Vello peat deposit, NW Spain, Org. Geochem., 38, 1097-1111, 2007.

Kaislahti Tillman, P., Holzkämper, S., Kuhry, P., Sannel, A. B. K., Loader, N. J., and Robertson, I.: Stable carbon and oxygen isotopes in sphagnum fuscum peat from subarctic canada: Implications for palaeoclimate studies, Chem. Geol., 270, 216-226, 2010.

Kalbitz, K., Geyer, W., and Geyer, S.: Spectroscopic properties of dissolved humic substances - a reflection of land use history in a fen area, Biogeochemistry, 47, 219-238, 1999.

Klavins, M., Sire, J., Purmalis, O., and Melecis, V.: Approaches to estimating humification indicators for peat, Mires Peat, 3, 1-15, 2008.

Kleinebecker, T., Hölzel, N., and Vogel, A.: Gradients of continentality and moisture in south patagonian ombrotrophic peatland vegetation, Folia Geobot., 42, 363-382, 2007. 
Kögel-Knabner, I.: The macromolecular organic composition of plant and microbial residues as inputs to soil organic matter, Soil Biol. Biochem., 34, 139-162, 2002.

Kracht, O. and Gleixner, G.: Isotope analysis of pyrolysis products from sphagnum peat and dissolved organic matter from bog water, Org. Geochem., 31, 645-654, 2000.

Kuder, T. and Kruge, M. A.: Preservation of biomolecules in subfossil plants from raised peat bogs - a potential paleoenvironmental proxy, Org. Geochem., 29, 1355-1368, 1998.

Kuhry, P. and Vitt, D. H.: Fossil carbon/nitrogen ratios as a measure of peat decomposition, Ecology, 77, 271-275, 1996.

Lafargue, E., Marquis, F., and Pillot, D.: Rock-eval 6 applications in hydrocarbon exploration, production, and soil contamination studies, Rev. I. Fr. Petrol., 53, 421-437, 1998.

Langford, F. F. and Blanc-Valleron, M.-M.: Interpreting rock-eval pyrolysis data using graphs of pyrolizable hydrocarbons vs. Total organic carbon, Am. Assoc. Petrol. Geol. Bull., 74, 799-804, 1990.

Loisel, J., Garneau, M., and Hélie, J.-F.: Modern Sphagnum $\delta^{13} \mathrm{C}$ signatures follow a surface moisture gradient in two boreal peat bogs, james bay lowlands, Québec, J. Quaternary Sci., 24, 209214, 2009.

Malmer, N. and Holm, E.: Variation in the $\mathrm{C} / \mathrm{N}$-quotient of peat in relation to decomposition rate and age determination with 210 pb, Oikos, 43, 171-182, 1984.

Malmer, N. and Wallén, B.: Input rates, decay losses and accumulation rates of carbon in bogs during the last millennium: Internal processes and environmental changes, Holocene, 14, 111-117, 2004.

Martínez Cortizas, A., Biester, H., Mighall, T., and Bindler, R.: Climate-driven enrichment of pollutants in peatlands, Biogeosciences, 4, 905-911, doi:10.5194/bg-4-905-2007, 2007.

McClymont, E. L., Bingham, E. M., Nott, C. J., Chambers, F. M., Pancost, R. D., and Evershed, R. P.: Pyrolysis gc-ms as a rapid screening tool for determination of peat-forming plant composition in cores from ombrotrophic peat, Org. Geochem., 42, 14201435, 2011.

McMullen, J. A., Barber, K. E., and Johnson, B.: A paleoecological perspective of vegetation succession on raised bog microforms, Ecol. Monogr., 74, 45-77, 2004.

Melillo, J. M., Aber, J. D., Linkins, A. E., Ricca, A., Fry, B., and Nadelhoffer, K. J.: Carbon and nitrogen dynamics along the decay continuum: Plant litter to soil organic matter, in: Ecology of Arable Land - Perspectives and Challenges, Springer, 53-62, 1989.

Ménot, G., and Burns, S. J.: Carbon isotopes in ombrogenic peat bog plants as climatic indicators: Calibration from an altitudinal transect in switzerland, Org. Geochem., 32, 233-245, 2001.

Mighall, T. M., Cortizas, A. M., Biester, H., and Turner, S. E.: Proxy climate and vegetation changes during the last five millennia in nw iberia: Pollen and non-pollen palynomorph data from two ombrotrophic peat bogs in the north western iberian peninsula, Rev. Palaeobot. Palyno., 141, 203-223, doi:10.1016/j.revpalbo.2006.03.013, 2006.

Niemeyer, J., Chen, Y., and Bollag, J.-M.: Characterization of humic acids, composts, and peat by diffuse reflectance fouriertransform infrared spectroscopy, Soil Sci. Soc. Am. J., 56, 135140, 1992.
Outridge, P. M. and Sanei, H.: Does organic matter degradation affect the reconstruction of pre-industrial atmospheric mercury deposition rates from peat cores? - a test of the hypothesis using a permafrost peat deposit in northern canada, Int. J. Coal Geol., 83, 73-81, 2010.

Pontevedra-Pombal, X., Martínez-Cortizas, A., García-Rodeja, E., Buurman, P., and Van Lagen, B.: Composición y transformación de la materia orgánica en un histosol de la serra do xistral (norte de galicia) mediante cpmas 13c-nmr, Edafología, 8, 67-79, 2001.

Pouwels, A. D., Tom, A., Eijkel, G. B., and Boon, J. J.: Characterisation of beech wood and its holocellulose and xylan fractions by pyrolysis-gas chromatography-mass spectrometry, J. Anal. Appl. Pyrol., 11, 417-436, 1987.

Price, G. D., McKenzie, J. E., Pilcher, J. R., and Hoper, S. T.: Carbon-isotope variation in sphagnum from hummock-hollow complexes: Implications for holocene climate reconstruction, Holocene, 7, 229-233, 1997.

Quay, P., Stutsman, J., Wilbur, D., Snover, A., Dlugokencky, E., and Brown, T.: The isotopic composition of atmospheric methane, Global Biogeochem. Cy., 13, 445-461, doi:10.1029/1998gb900006, 1999.

Rice, S. K. and Giles, L.: The influence of water content and leaf anatomy on carbon isotope discrimination and photosynthesis in sphagnum, Plant Cell Environ., 19, 118-124, 1996.

Robinson, D.: $\delta^{15} \mathrm{~N}$ as an integrator of the nitrogen cycle, Trends Ecol. Evol., 16, 153-162, 2001.

Schellekens, J. and Buurman, P.: $N$-alkane distributions as palaeoclimatic proxies in ombrotrophic peat: The role of decomposition and dominant vegetation, Geoderma, 164, 112-121, 2011.

Schellekens, J., Buurman, P., and Pontevedra-Pombal, X.: Selecting parameters for the environmental interpretation of peat molecular chemistry - a pyrolysis-gc/ms study, Org. Geochem., 40, 678691, 2009.

Schellekens, J., Buurman, P., Fraga, I., and Martínez-Cortizas, A.: Holocene vegetation and hydrologic changes inferred from molecular vegetation markers in peat, penido vello (galicia, spain), Palaeogeogr. Palaeocl., 299, 56-69, 2011.

Schellekens, J., Buurman, P., and Kuyper, T. W.: Source and transformations of lignin in carex-dominated peat, Soil Biol. Biochem., 53, 32-42, 2012.

Schellekens, J., Barberá, G. G., and Buurman, P.: Potential vegetation markers - analytical pyrolysis of modern plant species representative of neolithic se spain, J. Archaeol. Sci., 40, 365-379, 2013.

Schenk, H. J., Witte, E. G., Müller, P. J., and Schwochau, K.: Infrared estimates of aliphatic kerogen carbon in sedimentary rocks, Org. Geochem., 10, 1099-1104, 1986.

Schmidt, S. R., Kleinebecker, T., Vogel, A., and Holzel, N.: Interspecific and geographical differences of plant tissue nutrient concentrations along an environmental gradient in southern patagonia, chile, Aquat. Bot., 92, 149-156, doi:10.1016/j.aquabot.2009.11.002, 2010.

Senesi, N., Miano, T. M., Provenzano, M. R., and Brunetti, G.: Spectroscopic and compositional comparative characterization of i.H.S.S. Reference and standard fulvic and humic acids of various origin, Sci. Total Environ., 81-82, 143-156, 1989.

Senesi, N., Miano, T. M., Provenzano, M. R., and Brunetti, G.: Characterization, differentiation, and classification of humic sub- 
stances by fluorescence spectroscopy, Soil Sci., 152, 259-271, 1991.

Skrzypek, G., Kałuzny, A., Wojtuń, B., and Jedrysek, M.-O.: The carbon stable isotopic composition of mosses: A record of temperature variation, Org. Geochem., 38, 1770-1781, 2007.

Skrzypek, G., Baranowska-Kacka, A., Keller-Sikora, A., and Jedrysek, M.-O.: Analogous trends in pollen percentages and carbon stable isotope composition of holocene peat - possible interpretation for palaeoclimate studies, Rev. Palaeobot. Palyno., 156, 507-518, doi:10.1016/j.revpalbo.2009.04.014, 2009.

Smith, B. G. and Harris, P. J.: The polysaccharide composition of poales cell walls: Poaceae cell walls are not unique, Biochem. Syst. Ecol., 27, 33-53, 1999.

Steinmann, P., Huon, S., Roos-Barraclough, F., and Föllmi, K.: A peat core based estimate of late-glacial and holocene methane emissions from northern peatlands, Global Planet. Change, 53, 233-239, 2006.

Tissot, B. P. and Welte, D. H.: Petroleum formation and occurrence: A new approach to oil and gas exploration, Springer-Verlag, 1978.

van der Heijden, E. and Boon, J. J.: A combined pyrolysis mass spectrometric and light microscopic study of peatified calluna wood isolated from raised bog peat deposits, Org. Geochem., 22, 903-919, 1994 van der Heijden, E., Boon, J. J., and Scheijen, M. A.: Chemical characterisation of peat and peatified plant tissues by temperature resolved pyrolysis mass spectrometry and high temperature gas chromatography mass spectrometry, Peat 90 . International Conference on Peat Production and Use, 1, 148-163, 1990.

van der Heijden, E., Boon, J., Rasmussen, S., and Rudolph, H.: Sphagnum acid and its decarboxylation product isopropenylphenol as biomarkers for fossilised sphagnum in peats, Ancient Biomolecules, 1, 93-107, 1997.

van Smeerdijk, D. G. and Boon, J. J.: Characterisation of subfossil sphagnum leaves, rootlets of ericaceae and their peat by pyrolysis-high-resolution gas chromatography-mass spectrometry, J. Anal. Appl. Pyrol., 11, 377-402, 1987.

von Post, L.: Sveriges geologiska undersöknings torvinventering och några av dess hittills vunna resultat, Svenska Mosskulturföreningens Tidskrift, 1, 1-27, 1922.

Wende, G. and Fry, S. C.: 2-o- $\beta$-d-xylopyranosyl-(5-o-feruloyl)-1arabinose, a widespread component of grass cell walls, Phytochemistry, 44, 1019-1030, 1997.

Woodland, W. A., Charman, D. J., and Sims, P. C.: Quantitative estimates of water tables and soil moisture in holocene peatlands from testate amoebae, Holocene, 8, 261-273, 1998.

Yeloff, D. and Mauquoy, D.: The influence of vegetation composition on peat humification: Implications for palaeoclimatic studies, Boreas, 35, 662-673, 2006. 